$\mathrm{DOE} / \mathrm{MC} / 23172-\mathrm{T} 10$

DE92 017766

Determination of Physical and Mechanical properties of Copper-clad Molybdenum sheet

\title{
Report 34046
}

August 15,1988

\section{P.J. Grobner}

\section{DISCLAIMER}

This report was prepared as an account of work sponsored by an agency of the United States Government. Neither the United States Government nor any agency thereof, nor any of their employees, makes any warranty, en.,press or implied, or assumes any legal liability or responsibility for the accuracy, completeness, or usefulness of any information, apparatus, product, or process disclosed, or represents that its use would not infringe privately owned rights. Reference herein to any specific commercial product, process, or service by trade name, trademark, manufacturer, or otherwise does not necessarily constitute or imply its endorsement, recommendation, or favoring by the United States Government or any agency thereof. The views and opinions of authors expressed herein co not necessarily state or reflect those of the United States Government or any' agency thereof. 


\section{ABSTRACT}

Selected physical and mechanical properties of copper-clad molybdenum sheet have been determined. Among those properties determined were: room-temperature density, coefficient of thermal expansion in the temperature range -43 to $8010 \mathrm{C}$, specific heat between -40 and $+150 \mathrm{c}$, thermal conductivity from -50 to $+150 \mathrm{C}$, electrical resistivity in the same temperature range, magnetic susceptibility and modulus of elasticity both at room temperature. Materials with several different copper/molybdenum thickness ratios and composite thicknesses were evaluated. 


\section{INIRODUCTION}

Climax specialty Metals is producing copper-clad molybdenum sheet which is used in the electronic industry for thermal management. The copper-clad molybdenum sheet consists of roll-bonded laminates of OFHC copper on high purity (99.95\%) molybdenum. Different copper thickness ratios are being produced, the most common being $13,20,25$ and $33 \%$ per side, with total laminate thicknesses ranging from 0.13 to 13 $\mathrm{mm}(0.005$ to $0.50 \mathrm{in})$.

Effective use of copper-clad molybdenum sheet in electronic applications requires the knowledge of various physical and mechanical properties of the material. The properties of interest include density, coefficient of thermal expansion, specific heat, thermal conductivit, electrical resistivity, magnetic susceptibility and the mo ulus of elasticity. The present report summarizes the results of determinations of these properties. Table I lists the laboratories involved in the project and the temperature ranges over which tests were. conducted. The results of measurements obtained at the Thermophysical properties Research Laboratory of Purdue Laboratory (TPRL) are reported in TPRI $716^{1}$ and TPRL $716 A^{2}$. 
EXPERIMENTAL PROCEDURES

\section{MATERIAL}

Samples of copper-clad molybdenum sheet, about 300 by 300 by $1 \mathrm{~mm}$ ( 12 by 12 by 0.04 in.), with nominaliy $13,20,25$ and $33 \%$ cu per side, were received for determining the physical properties. In addition, an unclad molybdenum sheet of similar size was included in the test program. The modulus of elasticity was measured on flat tensile specimens machined from a different set of sheets, with nominally 5, 13, 20, 25, 33 and $38 \%$ Cu per side. All materials were mill stress relieved at $800 \mathrm{C}(1470 \mathrm{~F})$.

The actual thickness of the cladding was measured metallographically at ten locations on each side and the average values and standard deviations were calculated. Similar measurements were done, on the tensile specimens for Young's modulus. The results are given in Table II.

\section{DENSITY}

Two methods for determining the density were applied: by buoyancy and by measuring the weight and dimensions of the specimens. The determination by buoyancy was performed in duplicate according to the ASTM standard Method C 693-74 by weighing the specimens, about 68 by $65 \mathrm{~mm}(2.7$ by $2.2 \mathrm{in.})$, in air and in water. For the second method, slightly larger specimens, about 97 by $76 \mathrm{~mm}(3.8$ by $3.0 \mathrm{in.})$ were weighed to the nearest $0.1 \mathrm{mg}$ and their dimensions were measured to the nearest $0.01 \mathrm{~mm}$ at ten different locations to obtain a sufficiently accurate value of the volume. Each set of measurements was used to calculate the volume and the density, so that an average and a standard deviation could be evaluated.

\section{COEFFICIENT OF THERMAL EXPANSION}

The coefficient of thermal expansion (CTE) of copper cilad molybdenum sheet as well as of unclad molybdenum sheet was measured at the Thermophysical Properties Research Laboratory (TPRL) of Purdue University in the $X$ and $Y$ direction, using a dual Push-Rod Dilatometer. CTE was determined over two temperature ranges, one being $-43 \mathrm{C}$ to $+127 \mathrm{C}$ and the other 25 to $800 \mathrm{C}$. Measurements in the high temperature range were requested by Climax specialty Metals separately to obtain data useful for the production of ceramic coatings on the laminate. The specimens used were $50 \mathrm{~mm}$ (2 in.) long and $7 \mathrm{~mm}(0.28 \mathrm{in.})$ wide. 
The specific heat was measured at TPRL using a standard Perkin-Elmer Model DSC-2 Differential Scanning Calorimeter with sapphire as a reference material. The standard and sample, both encapsulated in pans, were subjected to the same heat flux and the differential power required to heat the samples at the same rate was recorded. The specific heat of the sample was computed from the mass of the sapphire standard, pans, the differential power and the known specific heat of sapphire. The measurements were conducted in the temperature range -40 to $+150 \mathrm{C}(-40$ to $+302 \mathrm{~F})$.

\section{THERMAL CONDUCTIVITY}

The thermal conductivity was measured in the temperature range -40 to $+150 \mathrm{C}(-40$ to $+302 \mathrm{~F})$ at TPRI using the Kohlrausch method which involves the determination of the product of thermal conductivity and electrical resistivity. since the electrical resistivity is also measured at the same time, . thermal conductivity can be calculated. The measurement was conducted by passing constant direct current through the specimen to heat it while the ends are kept at a constant temperature. Thermocouples also act as voltage probes. Radial heat losses are minimized by an external heater with a temperature profile matched with that of the specimen.

\section{ELECTRICAL RESISTIVITY}

Measurements in the temperature range -40 to $+150 \mathrm{C}$ $(-40$ to $+302 \mathrm{~F})$ were conducted at TPRL simultaneously when determining thermal conductivity.

\section{MAGNETIC SUSCEPTIBILITY}

Room temperature magnetic susceptibility was determined at the National Bureau of Standards, Electromagnetic Technology Division, in Boulder, colorado. The measurements were made with a SQUID magnetometer at applied fields of 10,20 and 50 oe.

\section{MODULUS OF ELASTICITY}

The specimens were tensile tested at room temperature in the elastic portion of the stress-strain curve to determine the modulus of elasticity. Strain was measured using foil strain gages. Two strain gages were bonded to the opposite faces of the specimen with epoxy cement and the circuit designed as a self compensating bridge. Ten measurements were made on each specimen; the load was removed after each test; a new load was applied and the stress-strain curve registered. No permanent strains were detected, indicating that all measurements were performed in the elastic region. Young's modulus was evaluated from the slope of the stress-strain line. 


\section{RESULTS AND DISCUSSION}

\section{DENSITY}

The results obtained at AMAX are given in Table III. They have good reproducibility and accuracy as indicated by the closeness of the results obtained by two independent methods and the low standard deviations which are in the range of $0,1$. to $1.0 \%$ of the average ralue. A plot of the data against the copper ratio in Figure 1 shows a linear correlation corresponding to the equation

$$
d=10.22-1.27 x
$$

where $d$ is the density in $g / \mathrm{cm}^{3}$ and $x$ is the ratio of tne total copper to the total thickness of the sheet. The theoretical density, calculated by weighed, averages, can be expressed by the equation

$$
d=10.22-1.28 x
$$

with a density of $10.22 \mathrm{~g} / \mathrm{cm}^{3}$ for molybdenum and $8.94 \mathrm{~g} / \mathrm{cm}^{3}$ for copper. ${ }^{3}$ The difference between the experimentally determined and theoretical equations is not statistically significant, so that the density of copper clad molybdenum sheet can be calculated when the actual copper thickness is known, using either equation.

It should be noted that density was also measured at TPRI as part of the determination of thermal conductivity. These results, reproduced in Table IV, (Table 6 of the Report TPRI 716) are systematically too low. It is inconceivable that the density of rolled molybdenum would be $9.97 \mathrm{~g} / \mathrm{cm}^{3}$. A possible explanation for the error can be the small size of the specimens, which makes accurate measurement of dimensions difficult (relative effect of burrs, etc.).

\section{COEFFICIENT OF THERMAL EXPANSION}

The results of measurements in the temperature range of -43 to $127 \mathrm{C}(-45$ to $261 \mathrm{~F})$ are given in Table $V$ which shows the average CTE between room temperature and $-43 C(-45 \mathrm{~F})$ and that between room temperature and $127 \mathrm{C}(261 \mathrm{~F})$. The data are plotted in Figure 2. The bar graph shows that the CTE generalIy increases with increasing copper ratios as expected. The testing direction has little effect on the test results. The only exceptions are the $-43 \mathrm{C}(-45 \mathrm{~F})$ data of the $25 \mathrm{Cu}$ samples, which are suspect, especially the measurement in the $x$ direction, which seems too low. The effect of the temperature range is different in the unclad molybdenum and the copper-clad samples. The unclad molybdenum has a higher CTE at the higher temperature, which agrees with data published in the litera- 
ture. In the copper-clad specimens, however, a lower CTE has been measured in the higher temperature range. This phenomenon can be explained by the effect of temperature on the strength of copper. Copper with its higher CTE tends to increase the CTE of the composite, but its influence will be stronger at low temperatures when it is stiffer and will diminish with increasing temperature as copper softens. The effect of temperature on the strength of molybdenum is negligible relative to its effect on that of copper.

Considering the small difference between the results obtained in the $X$ and $Y$ direction, the averages of the two were calculated for practical application with the exception of the suspect values of the $25 \mathrm{cu}$ material at low temperature. The data so obtained are plotted against the total copper ratio in Figure 3, showing a linear relation. This is probably an empirical observation without a strict theoretical basis, but it is useful to estimate the CTE of the $25 \mathrm{Cu}$ laminate at the lower temperature by interpolation $\left(7.45 \times 10^{-6} \mathrm{~K}^{-1}\right)$.

By averaging the results of the $X$ and $Y$ direction and estimating the CTE of the 25 Cu material at RT to $-43 C$ (RT to 45 F) by interpolation, a set of recommended data has been obtained and is summarized in the last column of Table $V$.

A second set of thermal expansion tests was conducted at TPRL between room temperature and $800 \mathrm{C}(1470 \mathrm{~F})$ and the results are presented in their Report TPRL $716 \mathrm{~A}^{3}$. The coefficients of thermal expansion calculated from the original experimental data (Table 1 in TPRL 716A) are given in Tabie VI. This table contains data obtained from the heating as well as the cooling paths. The difference between the results obtained in the $X$ and $Y$ direction is generally small enough that the average of the two values can serve as the single value. The exceptions are marked in the table. A comparison of the data obtajned in Figure 4 shows several inconsistencies in CTE values of the copper clad specimens.

The CTE of unclad molybdenum increases with increasing temperature, and there is little difference between results obtained during the heating and cooling period. The data for $200 \mathrm{C}(390 \mathrm{~F})$ are in reasonable agreement with those obtainebetween room temperature and $127 \mathrm{C}(260 \mathrm{~F})$, see Table V. Tise effect of the copper ratio is rather irregular. Little efiect is observed in the $13 \%, 20 \%$ and $25 \% \mathrm{Cu}$ laminates and only the $33 \% \mathrm{Cu}$ has a higher CTE. Similarly, the effect of the temperature range seems to be random with the possible tendency of an increase of CTE with increasing temperature. Striking are the many cases with a large difference between the results obtained during the heating and the cooling cycle. In most of these the data from the cooling cycle are lower than the corresponding data from the heating cycle. A possible reason for this 
behavior was found when examining the tested specimens, which all show a distinct oxide layer. The growing oxide will simulate a higher expansion during the heating cycle, but retard the contraction during the cooling cycle.

The data obtained on copper clad molybdenum sheet in this set of tests seem questionable and the tests should be repeated under conditions preventing oxidation of the specimens.

\section{SPECIFIC HEAT}

The results of measurements at TPRL are shown in Table VII and Figure 5. The data are quite consistent with the expected effect of the copper ratio according to the rule of mixtures. The specific heats at $21 \mathrm{C}(70 \mathrm{~F})$ are plotted against the copper ratio in Figure 6 . The effect of the copper ratio $x$ on the specific heat can be expressed by the equation:

$$
c=\frac{x\left(d_{C u} c_{C u}-d_{M O} c_{M O}\right)+d_{M O} c_{M O}}{x\left(d_{C u}-d_{M O}\right)+d_{M O}}
$$

where $x$ is the copper ratio

$\mathrm{d}_{\mathrm{Cu}}$ is the density of copper

$d_{M O}$ is the density of molybdenum

$c_{C u}$ is the specific heat of copper

$c_{\text {Mo }}$ is the specific heat of molybdenum

The room temperature density of copper is $8.94 \mathrm{~g} / \mathrm{cm}^{3}$ and that of molybdenum is $10.22 \mathrm{~g} / \mathrm{cm}^{3}$. The specific heats of molybdenum and copper at $21 \mathrm{C}(70 \mathrm{~F})$ are 0.387 and $0.247 \mathrm{~W}_{\mathrm{S}} / \mathrm{gK}$

respectively according to data in Reference 4 . When using these values in equation (1) the following formula is obtained.

$$
c=\frac{0.935 x+2.524}{-1.280 x+10.22}
$$

The corresponding curve is plotted in Figure 6 and the diagram shows an excellent agreement between the experimental data and the theoretical plot.

\section{THERMA L CONDUCTIVITY}

The results of the in-place ( $X$ and $Y$ direction) theimal conductivity (TC) measurements at TPRL are presented in Table VIII and are plotted against testing temperature in Figure 7 . The diagram indicates that temperature has little systematic effect on thermal conductivity in the range tested, although it is known ${ }^{4}$ that the TC of copper as well as of molybdenum decreases with increasing temperature. The effect of tempera- 
ture was tested statistically by calculating the slope "a" of the linear regression equation

$$
T C=a t+b
$$

where $t$ is the temperature in centigrade. The results are presented in Table IX. Some of the data are negative (as expected), but some are positive and their values don't exceed $2.22 \times 10^{-4}$, which indicates that there is no statistically significant effect of temperature in this range. An average TC for the temperature range of -50 to $150 \mathrm{C}(-58$ to $300 \mathrm{~F})$ can therefore be assumed.

Figure 7 also shows little difference between the data points obtained in the $X$ and the $Y$ direction. An exception is the $33 \% \mathrm{Cu}$ material, where the results are slightly, yet systematically lower in the $Y$ direction than in the $X$ direction. But even in this case the difference in the means is within one standard deviation, so that the two sets of data can be considered as one for practical purposes and an average can be established. The calculated values and the corresponding standard deviations are given in the last row of Table VIII. These data are plotted against the copper ratio in Figure 8 , showing a linear correlation. The unexpectedly low value for the $20 \%$ cu material can not be explained.

Results of thermal conductivity measurements at TPRL in the $\mathrm{Z}$ direction (through thickness) are reproduced in Table $X$. The effect of temperature is consistent in the $0 \% \mathrm{Cu}, 13 \% \mathrm{Cu}$ and $25 \% \mathrm{Cu}$ material (TC drops with temperature) while the 20 and $33 \% \mathrm{Cu}$ results show irregularities. The room-temperature TC increases with the copper ratio between 0 and $25 \% \mathrm{Cu}$, but the $33 \% \mathrm{Cu}$ result is almost identical with that of the $25 \% \mathrm{Cu}$ material. This anomaly may be due to poor thermal contact between the layers.

\section{ELECTRICAL RESISTIVITY}

Electrical resistivity was measured at TPRI in the temperature range of - 50 to $150 \mathrm{C}(-58$ to $300 \mathrm{~F})$ as part of the thermal conductivity determination. The results obtained are given in Table XI. A plot of the data against temperature in Figure 9 shows that the temperature dependence is linear and that the difference between the $X$ and $Y$ data is practically negligible. There is practically no difference between the electrical resistivity observed in the $13 \% \mathrm{Cu}$ and $20 \% \mathrm{Cu}$, which is difficult to explain. It could be related to the large scatter of the copper ratio in the $20 \% \mathrm{Cu}$ product (see Table 2).

The linear regression coefficients of the temperature dependence were calculated by the least square method and are 
listed in Table XII together with the coefficients of correlation and the calculated values of electrical resistivity for $25 \mathrm{C}(77 \mathrm{~F})$. These data are plotted against the total copper thickness ratio in Figure 10, which shows, with the exception of the $20 \%$ cu value, a good agreement with the theoretical. curve. This curve was derived from the general formula for electrical resistance for parallel resistors.

$$
1 / R=1 / R_{1}+1 / R_{2}+\cdots
$$

which leads to the equation

$$
E R=\frac{E R \text { Mo }}{x\left(E R_{M O} / E R_{C u}-1\right)+1}
$$

where $E R_{M O}$ and $E R_{C u}$ are the electrical resistivities of molybdenum and copper and $x$ is the total copper ratio in the laminate. Using $\mathrm{ER}_{\mathrm{MO}}=5.7 \mathrm{\mu \Omega cm}$ according to Reference 3 , Equation (3) becomes

$$
E R=\frac{5.7}{2.365 x+1}
$$

The curve in Figure 10 corresponds to this equation. MAGNETIC SUSCEPTIBILITY

Room-temperature magnetic susceptibility was measured at the National Bureau of Standards in Boulder, Colorado. The results are given in Table XIII and are plotted in Figure 11 against the copper thickness ratio. The plot shows that magnetic susceptibility decreases linearly with the copper ratio.

\section{MODULUS OF ELASTICITY}

The results of the mechanical tests to determine Young's modulus are given in Table XIV. They have good reproducibility as indicated by their low standard deviations which are systematically below $2 \%$ of the average. Young's modulus of the unclad molybdenum sheet is well within the values reported in the literature. Smithells and Brandes ${ }^{5}$, for example, give a value of $324.8 \mathrm{GPa}\left(47.1 \times 10^{6} \mathrm{psi}\right)$, while an older edition of

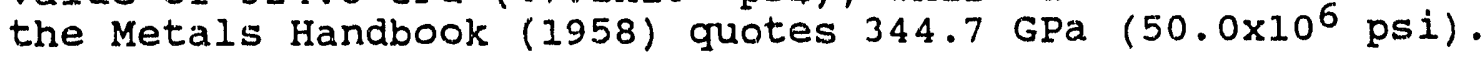

A plot of the data against the copper ratio in Figure 12 shows a non-linear correlation, corresponding to a quadratic equation

$$
y=a+b x+c x^{2}
$$


The curve in Figure 12 was calculated from the experimental data using the least square regression of this formula, leading to the equation for Young's modulus in GPa

$$
E=336.8-93.795 x-108.011 x^{2}
$$

where $x$ is the ratio of total copper to the total thickness of the specimen. The cause of the non-linear correlation is most probably internal stress in the copper layer which changes with $i$ is thickness. The internal stress is generated in the copper during cooling from the stress relieving temperature of $800^{\circ} \mathrm{C}$. $\left(1470^{\circ} \mathrm{F}\right)$ when the much stiffer molybdenum core shrinks less (coefficient of expansion $=5.1 \times 10^{-6} / \mathrm{K}$ ) than the copper cladding, (coefficient of expansion of $17.0 \times 10^{-6} / \mathrm{K}$ ). When extrapolating the curve to a copper ratio of 1 according to Equation 2, a hypothetical modulus of elasticity of $135.0 \mathrm{GPa}$

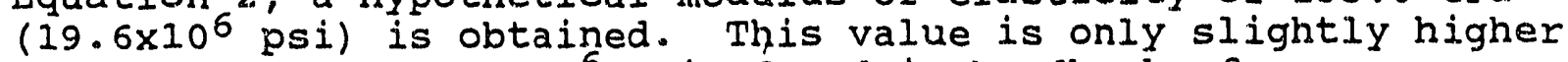
than $129.8 \mathrm{GPa}\left(18.8 \times 10^{6} \mathrm{psi}\right)$ found in handbooks for copper.

AMAX Research \& Developmont Center

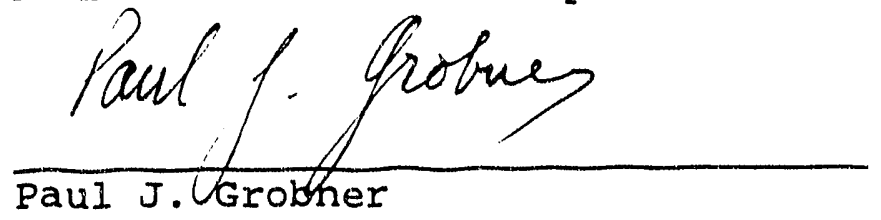




\section{REFERENCES}

1. R.E. Taylor, H. Groot and J. Larimore, "Thermophysical Properties of Copper and Aluminum Clad Molybdenum", Report to TPRL 716, Thermophysical Properties Research

Laborctory, purdue University, West Lafayette, IN, April, 1988 .

2. R.E. Taylor, "Thermal Expansion of $\mathrm{Cu} / \mathrm{Mo} / \mathrm{Cu}$ ", Report TPLLL 716A, Thermophysical properties Research Laboratory, Purdue University, West Lafayette, IN, March, 1988.

3. C.J. Smithells and E.A. Brandes, "Metals Reference Book", Butcerworths, London, UK, 1987.

4. J.H. Perry, "Chemical Engineer's Handbook", 4th edition, McGraw-Hill, New York, NY, 1963.

5. "Metals Handbook", Vol. 2, 9th Edition, Amer. Soc. for Metals, Metals Park, OH, 1979 


\section{Tat le I Tests Performed}

\section{Property.}

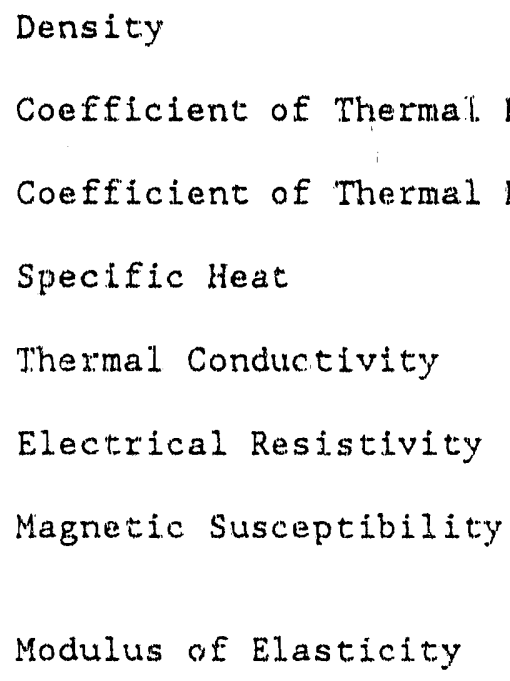

Laboratory

AMAX R\&D Center

Purdue University

Purdue University

Puidue University

Puraue University

Purdue University

National Bureau of Standards

AMAX R\&D Center
Temperature

Room Temperature

$-43 C$ to $+127 C$

25 to $800 \mathrm{C}$

$-40 \mathrm{C}$ to $+150 \mathrm{C}$

$-50 \mathrm{C}$ to $+150 \mathrm{C}$

-50 C to t $150 \mathrm{C}$

Room Temperature

Room Temperature 


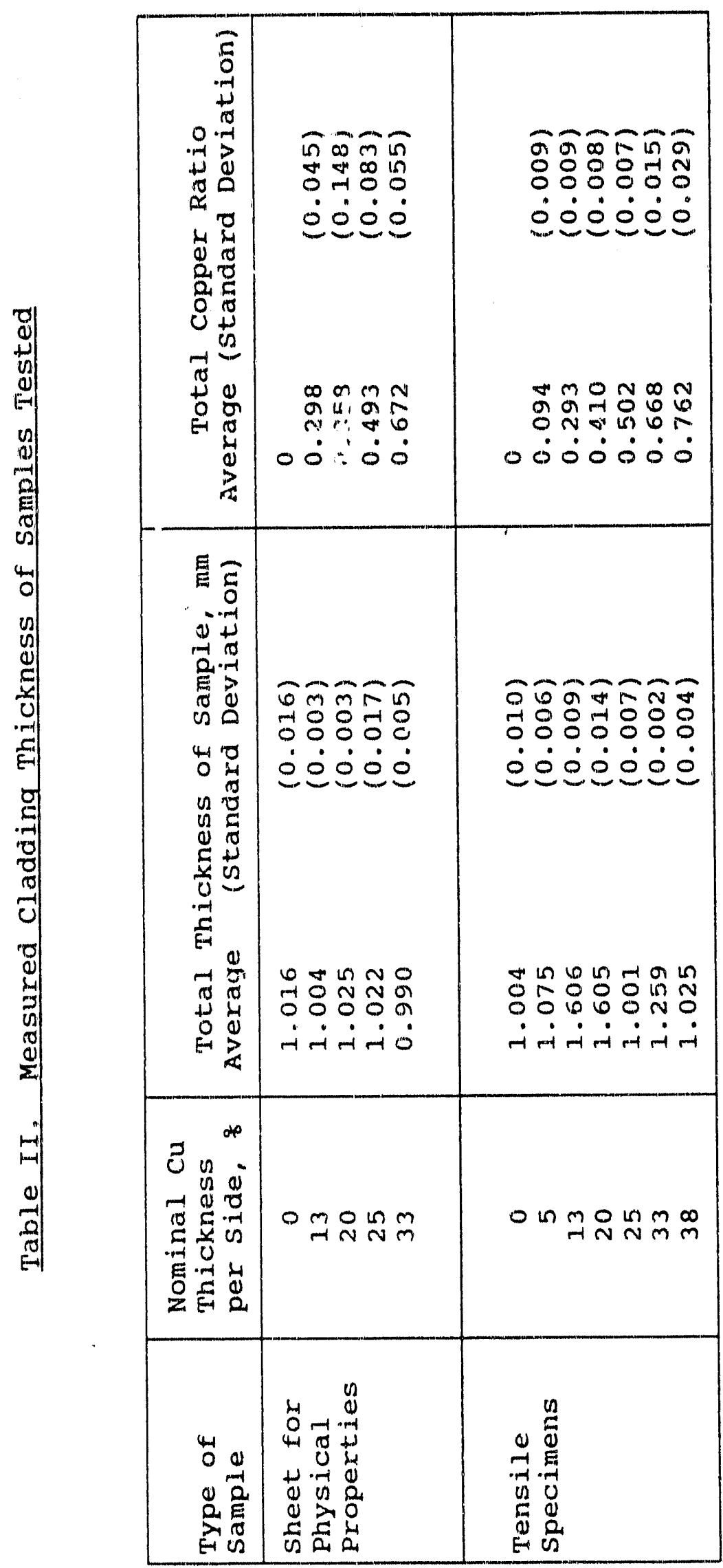


Table III. Densit' of Copper Clad Molybdenum Sheet

\begin{tabular}{|c|c|c|c|c|}
\hline \multirow{2}{*}{$\begin{array}{l}\text { Nominal cu } \\
\text { Ratio per } \\
\text { Side, }\end{array}$} & $\begin{array}{c}\text { Measured } \\
\text { Total } \\
\text { Cu Ratio }\end{array}$ & $\begin{array}{c}\text { Buoyancy } \\
\text { Methoda }\end{array}$ & $\begin{array}{c}\text { Dimension Measure- } \\
\text { ment Method }\end{array}$ & $\begin{array}{c}\text { Average of } \\
\text { Both Methods }\end{array}$ \\
\cline { 3 - 5 } & & & & \\
0 & 0 & 10.22 & $10.22 \pm 0.05^{\mathrm{b}}$ & 10.22 \\
13 & 0.298 & 9.85 & $9.83 \pm 0.02$ & 9.84 \\
20 & 0.358 & 9.80 & $9.76 \pm 0.01$ & 9.78 \\
25 & 0.493 & 9.59 & $9.58 \pm 0.10$ & 9.59 \\
33 & 0.672 & 9.38 & $9.35 \pm 0.02$ & 9.37 \\
\hline
\end{tabular}

\section{a Average of two specimens}

$b$ Standard Deviation

Table IV. Sample Geometries, Masses and Bulk Density Values*

\begin{tabular}{|c|c|c|c|c|c|}
\hline $\begin{array}{c}\text { Sample } \\
\text { Designation }\end{array}$ & $\begin{array}{c}\text { l'hick } \\
\text { (in) }\end{array}$ & $\begin{array}{c}\text { Width } \\
\text { (in) }\end{array}$ & $\begin{array}{c}\text { Width } \\
\text { (in) }\end{array}$ & $\begin{array}{c}\text { Mass } \\
(\mathrm{gms})\end{array}$ & $\begin{array}{c}\text { Density } \\
\left(\mathrm{gms} \mathrm{cm}^{-3}\right)\end{array}$ \\
\hline Mo & 0.0400 & 0.4867 & 0.482 & 1.5337 & 9.974 \\
$13 \%$ & 0.0408 & 0.4860 & 0.485 & 1.5024 & 9.533 \\
$20 \%$ & 0.0405 & 0.4855 & 0.487 & 1.5063 & 9.599 \\
$25 \%$ & 0.0424 & 0.486 & 0.486 & 1.5354 & 9.356 \\
$33 \%$ & 0.0405 & 0.486 & 0.489 & 1.4435 & 9.152 \\
\hline
\end{tabular}

* From Report TPRL716 
Table V. Coefficients of Thermal Expansion (CTE). Between RT to $-43 \mathrm{C}$ and RT to $127 \mathrm{C}$

\begin{tabular}{|c|c|c|c|c|c|}
\hline \multirow{2}{*}{$\begin{array}{l}\text { Nominal } \\
\text { Cu } \\
\text { Ratio, } \\
\frac{\%}{6}\end{array}$} & \multirow{2}{*}{\multicolumn{2}{|c|}{$\begin{array}{l}\text { Temperature Range, } \\
\text { C }\end{array}$}} & \multicolumn{2}{|c|}{ CTE, $10^{-6} \mathrm{~K}^{-1}$ in the } & \multirow{2}{*}{$\begin{array}{c}\text { Average } \\
\text { CTE, } \\
10^{-6} \mathrm{~K}^{-1}\end{array}$} \\
\hline & & & $\mathrm{x}$ Direction & Y Direction & \\
\hline 0 & $\begin{array}{l}\text { RT to }-43 \\
\text { RT to } 127\end{array}$ & $\begin{array}{l}(\mathrm{RT} t=-45) \\
\text { (RT to } 261)\end{array}$ & $\begin{array}{l}5.00 \\
5.32\end{array}$ & $\begin{array}{l}4.97 \\
5.25\end{array}$ & $\begin{array}{l}4.99 \\
5.29\end{array}$ \\
\hline 13 & $\begin{array}{l}\mathrm{RT} \text { to }-43 \\
\mathrm{RT} \text { to } 127\end{array}$ & $\begin{array}{l}\text { (RT to }-45) \\
\text { (RT to } 261)\end{array}$ & $\begin{array}{l}5.66 \\
5.70\end{array}$ & $\begin{array}{l}6.14 \\
5.52\end{array}$ & $\begin{array}{l}5.90 \\
5.61\end{array}$ \\
\hline 20 & $\begin{array}{l}\text { RT to }-43 \\
\text { RT to } 127\end{array}$ & $\begin{array}{l}\text { (RT to }-45) \\
\text { (RT to } 261)\end{array}$ & $\begin{array}{l}6.26 \\
5.91\end{array}$ & $\begin{array}{l}6.45 \\
5.97\end{array}$ & $\begin{array}{r}6.36 \\
-5.94\end{array}$ \\
\hline 25 & $\begin{array}{l}\text { RT to }-43 \\
\text { RT to } 127\end{array}$ & $\begin{array}{l}\text { (RT to }-45) \\
\text { (RT to } 261)\end{array}$ & $\begin{array}{l}5.89 \\
6.67\end{array}$ & $\begin{array}{l}7.97 \\
7.07\end{array}$ & $\begin{array}{l}7.43 * \\
6.87\end{array}$ \\
\hline 33 & $\begin{array}{l}\text { RT to }-4 j \\
\text { RT to } 127\end{array}$ & $\begin{array}{l}\text { (RT to }-45) \\
\text { (Rt to } 261)\end{array}$ & $\begin{array}{l}8.88 \\
7.96\end{array}$ & $\begin{array}{l}8.82 \\
8.07\end{array}$ & $\begin{array}{l}8.85 \\
8.02\end{array}$ \\
\hline
\end{tabular}

* Interpolated value 
Table VI. Coefficients of Thermal Expansion Between Room Temperature and $800 \mathrm{C}(1470 \mathrm{~F})$

\begin{tabular}{|c|c|c|c|c|c|c|}
\hline \multirow{2}{*}{$\begin{array}{l}\text { Cu } \\
\text { atio, } \\
\frac{8}{8}\end{array}$} & \multirow{2}{*}{$\begin{array}{l}\text { Temperature } \\
\text { Range, RT to } \\
\text { C } \quad(F)\end{array}$} & \multirow[b]{2}{*}{ Cycle } & \multicolumn{2}{|c|}{$\mathrm{CTE}, 10^{-6} \mathrm{~K}^{-1}$} & \multirow{2}{*}{$\begin{array}{c}X-Y \\
\text { Average } \\
\text { CTE } \\
10^{-6} \mathrm{~K}^{-1}\end{array}$} & \multirow{2}{*}{$\begin{array}{c}\mathrm{H}-\mathrm{C} \\
\text { Average } \\
\text { CTE } \\
10^{-6} \mathrm{~K}^{-1}\end{array}$} \\
\hline & & & $\begin{array}{l}\text { X Direc- } \\
\text { tion }\end{array}$ & $\begin{array}{l}Y \text { Direc- } \\
\text { tion }\end{array}$ & & \\
\hline \multirow[t]{4}{*}{0} & $(390)$ & $\begin{array}{l}\mathrm{H} \\
\mathrm{C} \\
\end{array}$ & $\begin{array}{l}5.19 \\
5.21 \\
\end{array}$ & $\begin{array}{l}5.31 \\
5.32 \\
\end{array}$ & $\begin{array}{l}5.25 \\
5.27 \\
\end{array}$ & 5.26 \\
\hline & $(750)$ & $\begin{array}{l}\mathrm{H} \\
\mathrm{C}\end{array}$ & $\begin{array}{l}5.49 \\
5.37 \\
\end{array}$ & $\begin{array}{l}5.35 \\
5.35 \\
\end{array}$ & $\begin{array}{l}5.42 \\
5.36 \\
\end{array}$ & 5.39 \\
\hline & $600 \quad(1110)$ & $\begin{array}{l}\mathrm{H} \\
\mathrm{C}\end{array}$ & $\begin{array}{l}5.54 \\
5.54 \\
\end{array}$ & $\begin{array}{l}5.49 \\
5.50 \\
\end{array}$ & $\begin{array}{l}5.52 \\
5.52 \\
\end{array}$ & 5.52 \\
\hline & $800 \quad(1470)$ & $\begin{array}{l}\mathrm{H} \\
\mathrm{C} \\
\end{array}$ & $\begin{array}{l}5.69 \\
5.68 \\
\end{array}$ & $\begin{array}{l}5.66 \\
5.67 \\
\end{array}$ & $\begin{array}{l}5.68 \\
5.68 \\
\end{array}$ & 5.68 \\
\hline \multirow[t]{4}{*}{13} & $(390)$ & $\begin{array}{l}\mathrm{H} \\
\mathrm{C}\end{array}$ & $\begin{array}{l}5.69 \\
5.38 \\
\end{array}$ & $\begin{array}{l}5.98 \\
5.14 \\
\end{array}$ & $\begin{array}{l}5.84 \\
5.26 \\
\end{array}$ & $\begin{array}{c}5.55^{\mathrm{a}} \\
.\end{array}$ \\
\hline & $(750)$ & $\begin{array}{l}\mathrm{H} \\
\mathrm{C}\end{array}$ & $\begin{array}{l}5.60 \\
5.57 \\
\end{array}$ & $\begin{array}{l}5.70 \\
5.51 \\
\end{array}$ & $\begin{array}{l}5.65 \\
5.54 \\
\end{array}$ & 5.60 \\
\hline & $600 \quad(1110)$ & $\begin{array}{l}\mathrm{H} \\
\mathrm{C}\end{array}$ & $\begin{array}{l}5.32 \\
5.68 \\
\end{array}$ & $\begin{array}{l}5.73 \\
5.06 \\
\end{array}$ & $\begin{array}{l}5.53 \\
5.37^{a} \\
\end{array}$ & 5.45 \\
\hline & $(1470)$ & $\begin{array}{l}\mathrm{H} \\
\mathrm{C}\end{array}$ & $\begin{array}{l}5.87 \\
5.79 \\
\end{array}$ & $\begin{array}{r}5.91 \\
4.84 \\
\end{array}$ & $\begin{array}{l}5.89 \\
5.32^{\mathrm{a}} \\
\end{array}$ & $5.61^{\mathrm{a}}$ \\
\hline \multirow[t]{4}{*}{20} & $(390)$ & $\begin{array}{l}\mathrm{H} \\
\mathrm{C}\end{array}$ & $\begin{array}{l}5.73 \\
5.44 \\
\end{array}$ & $\begin{array}{l}6.15 \\
5.57 \\
\end{array}$ & $\begin{array}{l}5.94 \\
5.51 \\
\end{array}$ & $5.73^{\mathrm{a}}$ \\
\hline & $(750)$ & $\begin{array}{l}\mathrm{H} \\
\mathrm{C} \\
\end{array}$ & $\begin{array}{l}5.63 \\
5.62 \\
\end{array}$ & $\begin{array}{l}5.61 \\
5.71 \\
\end{array}$ & $\begin{array}{l}5.62 \\
5.67 \\
\end{array}$ & 5.65 \\
\hline & $600 \quad(.2110)$ & $\begin{array}{l}\mathrm{H} \\
\mathrm{C}\end{array}$ & $\begin{array}{l}5.44 \\
5.74 \\
\end{array}$ & $\begin{array}{l}5.40 \\
5.83 \\
\end{array}$ & $\begin{array}{l}5.42 \\
5.79 \\
\end{array}$ & 5.61 \\
\hline & $800 \quad(1.470)$ & $\begin{array}{l}\mathrm{H} \\
\mathrm{C} \\
\end{array}$ & $\begin{array}{l}6.15 \\
5.77 \\
\end{array}$ & $\begin{array}{l}5.91 \\
5.96 \\
\end{array}$ & $\begin{array}{l}6.03 \\
5.87 \\
\end{array}$ & 5.95 \\
\hline \multirow[t]{4}{*}{25} & $(390)$ & $\begin{array}{l}\mathrm{H} \\
\mathrm{C}\end{array}$ & $\begin{array}{l}6.39 \\
5.02 \\
\end{array}$ & $\begin{array}{l}7.59 \\
5.22 \\
\end{array}$ & $\begin{array}{l}6.99^{\mathrm{a}} \\
5.19^{2} \\
\end{array}$ & $5.59^{\mathrm{a}}$ \\
\hline & $(750)$ & $\begin{array}{l}\mathrm{H} \\
\mathrm{C}\end{array}$ & $\begin{array}{l}5.63 \\
5.50 \\
\end{array}$ & $\begin{array}{l}6.40 \\
5.31 \\
\end{array}$ & $\begin{array}{l}6.02 \\
5.41 \\
\end{array}$ & $5.72^{\mathrm{a}}$ \\
\hline & $600 \quad(1110)$ & $\begin{array}{l}\mathrm{H} \\
\mathrm{C} \\
\end{array}$ & $\begin{array}{l}5.17 \\
5.73 \\
\end{array}$ & $\begin{array}{l}5.71 \\
5.47 \\
\end{array}$ & $\begin{array}{l}5.44 \\
5.60 \\
\end{array}$ & 5.52 \\
\hline & $800 \quad(1470)$ & $\begin{array}{l}\mathrm{H} \\
\mathrm{C} \\
\end{array}$ & $\begin{array}{l}5.49 \\
6.01 \\
\end{array}$ & $\begin{array}{l}6.08 \\
5.16 \\
\end{array}$ & $\begin{array}{l}5.79 \\
5.59 \mathrm{a} \\
\end{array}$ & 5.69 \\
\hline \multirow[t]{4}{*}{33} & $(390)$ & $\begin{array}{l}\mathrm{H} \\
\mathrm{C} \\
\end{array}$ & $\begin{array}{l}8.13 \\
5.62 \\
\end{array}$ & $\begin{array}{l}6.55 \\
5.62 \\
\end{array}$ & $\begin{array}{l}7.34 a^{a} \\
5.64\end{array}$ & $6.59^{a}$ \\
\hline & $(750)$ & $\mathrm{H}$ & $\begin{array}{l}6.54 \\
5.81 \\
\end{array}$ & $\begin{array}{l}5.93 \\
5.84 \\
\end{array}$ & $\begin{array}{l}5.24 \\
5.83 \\
\end{array}$ & $6.04^{\mathrm{a}}$ \\
\hline & $600 \quad(1100)$ & $\begin{array}{l}\mathrm{H} \\
\mathrm{C} \\
\end{array}$ & $\begin{array}{l}6.05 \\
5.93 \\
\end{array}$ & $\begin{array}{l}5.74 \\
6.09 \\
\end{array}$ & $\begin{array}{l}5.90 \\
6.01 \\
\end{array}$ & 5.96 \\
\hline & $(1470)$ & $\begin{array}{l}\mathrm{H} \\
\mathrm{C}\end{array}$ & $\begin{array}{l}6.22 \\
6.26\end{array}$ & $\begin{array}{l}5.85 \\
6.39\end{array}$ & $\begin{array}{l}6.04 \\
6.33\end{array}$ & 6.18 \\
\hline
\end{tabular}

a These averages are taken from two widely different values and are therefore suspect. 
Table VII. Specific Heats of Copper-Clad Molybdenum sheet

\begin{tabular}{|r|c|c|c|c|c|c|}
\hline \multicolumn{2}{|c|}{} & \multicolumn{5}{|c|}{$\begin{array}{r}\text { Specific Heat of Sheets of the Nominal } \\
\text { Copper Ratio Indicated, Ws/gK }\end{array}$} \\
\hline Temperature & $(F)$ & 0 & 13 & 20 & 25 & 33 \\
\hline & & & & & & \\
-30 & $(-40)$ & 0.237 & 0.269 & 0.274 & 0.297 & 0.319 \\
-20 & $(-22)$ & 0.239 & 0.272 & 0.277 & 0.299 & 0.321 \\
-10 & $(-4)$ & 0.242 & 0.274 & 0.281 & 0.302 & 0.323 \\
0 & $(14)$ & 0.244 & 0.277 & 0.283 & 0.304 & 0.325 \\
& $(32)$ & 0.246 & 0.280 & 0.286 & 0.306 & 0.328 \\
11 & $(52)$ & 0.248 & 0.282 & 0.288 & 0.309 & 0.330 \\
21 & $(70)$ & 0.250 & 0.285 & 0.291 & 0.312 & 0.332 \\
31 & $(88)$ & 0.252 & 0.287 & 0.294 & 0.314 & 0.334 \\
41 & $(106)$ & 0.254 & 0.289 & 0.296 & 0.316 & 0.335 \\
51 & $(124)$ & 0.255 & 0.291 & 0.298 & 0.318 & 0.339 \\
& & & & & & \\
61 & $(142)$ & 0.255 & 0.293 & 0.300 & 0.320 & 0.341 \\
71 & $(160)$ & 0.258 & 0.295 & 0.303 & 0.322 & 0.343 \\
81 & $(178)$ & 0.258 & 0.297 & 0.304 & 0.324 & 0.345 \\
91 & $(196)$ & 0.260 & 0.298 & 0.306 & 0.325 & 0.346 \\
101 & $(214)$ & 0.261 & 0.299 & 0.307 & 0.326 & 0.348 \\
111 & $(232)$ & 0.262 & 0.300 & 0.308 & 0.328 & 0.349 \\
121 & $(250)$ & 0.263 & 0.301 & 0.310 & 0.329 & 0.350 \\
125 & $(257)$ & 0.264 & 0.301 & 0.310 & 0.329 & 0.350 \\
150 & $(302)$ & 0.266 & 0.304 & 0.313 & 0.332 & 0.354 \\
\hline
\end{tabular}




\begin{tabular}{|c|c|c|c|c|}
\hline \multirow{2}{*}{$\begin{array}{l}\tilde{J} \\
\text { olo } \\
m \\
m\end{array}$} & 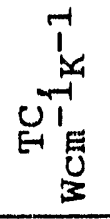 & 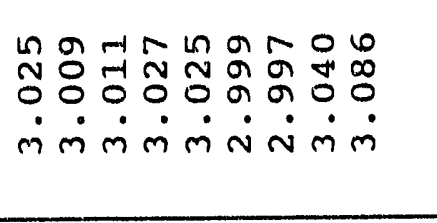 & 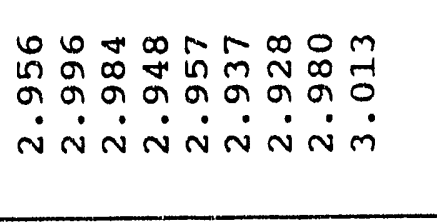 & 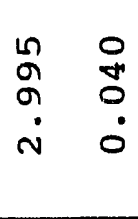 \\
\hline & 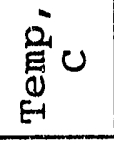 & î่ & 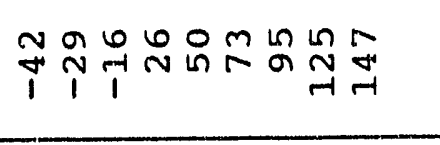 & \\
\hline \multirow{2}{*}{ 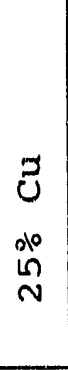 } & 臬 & 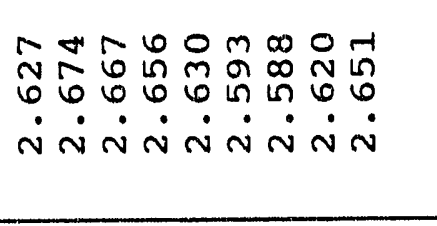 & 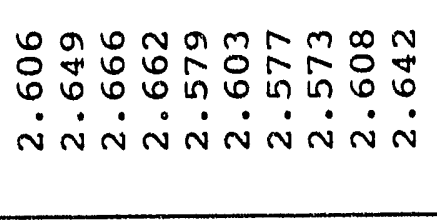 & 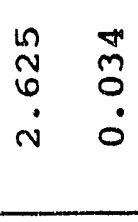 \\
\hline & 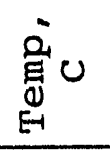 & 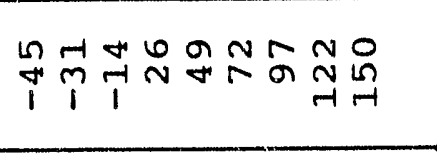 & îำ & \\
\hline \multirow{2}{*}{$\begin{array}{l}J \\
U \\
\text { olo } \\
O\end{array}$} & 萑 & 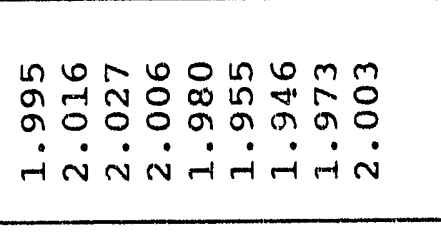 & 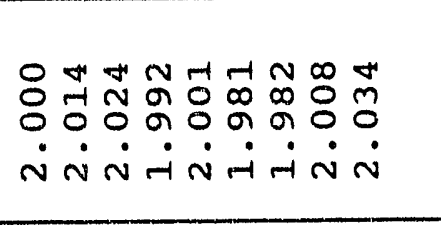 & 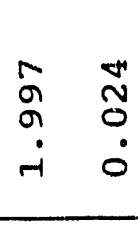 \\
\hline & 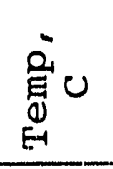 & 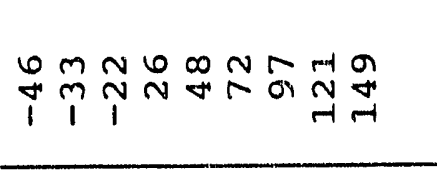 & 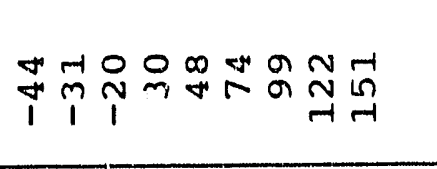 & \\
\hline \multirow{2}{*}{$\begin{array}{l}3 \\
U \\
m \\
-1\end{array}$} & 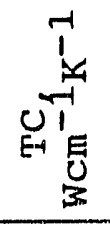 & 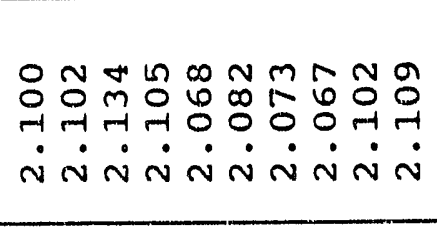 & 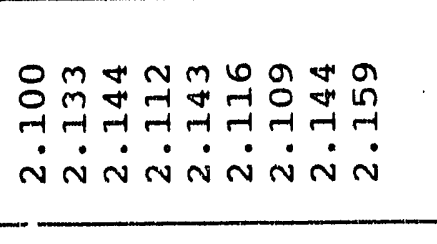 & 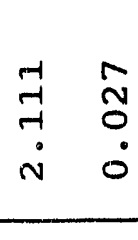 \\
\hline & 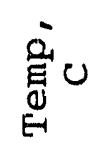 & 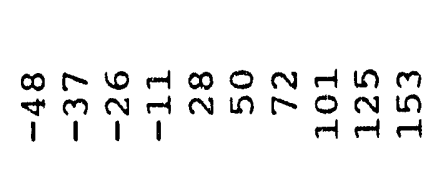 & i & \\
\hline \multirow{2}{*}{$\begin{array}{l}3 \\
0 \\
010 \\
0\end{array}$} & 先 & 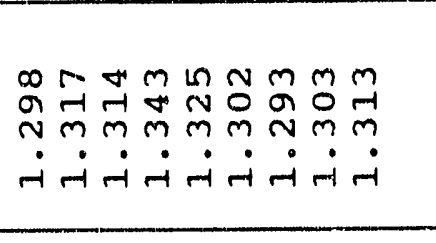 & 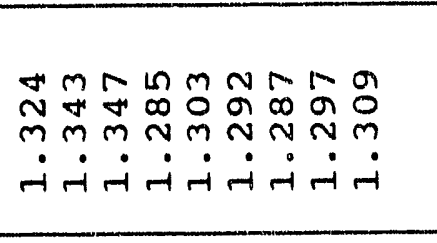 & $\begin{array}{ll}\stackrel{-1}{1} & 0 \\
r & -1 \\
& 0 \\
-1 & 0\end{array}$ \\
\hline & 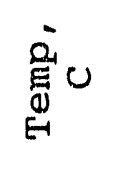 & 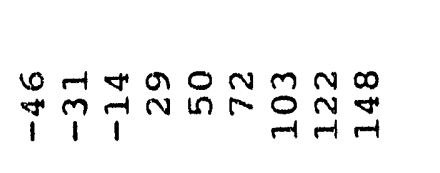 & 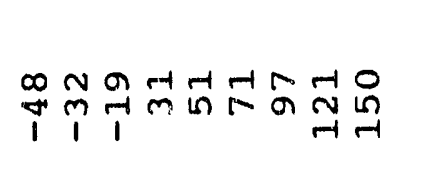 & \\
\hline 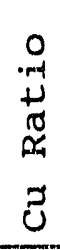 & 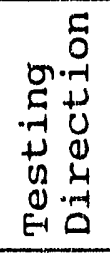 & $x$ & $>1$ & 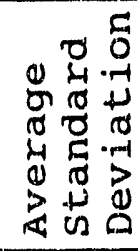 \\
\hline
\end{tabular}


Table IX. Slopes of the Linear Reqression Equation

$$
T C=a t+b
$$

\begin{tabular}{|c|c|c|}
\hline $\begin{array}{l}\text { Nominal } \mathrm{Cu} \\
\text { Ratio, } \%\end{array}$ & $\begin{array}{c}\text { Testing } \\
\text { Direction }\end{array}$ & $\begin{array}{c}\text { Slope } \\
\text { "a" }\end{array}$ \\
\hline 0 & $\mathrm{X}$ & $\begin{array}{l}-4.22 \times 10^{-5} \\
-2.22 \times 10^{-4}\end{array}$ \\
\hline 13 & $\mathrm{Y}$ & $\begin{array}{l}-8.99 \times 10^{-5} \\
+1.19 \times 10^{-4}\end{array}$ \\
\hline 20 & $\mathrm{Y}$ & $\begin{array}{l}-2.16 \times 10^{-4} \\
+2.56 \times 10^{-6}\end{array}$ \\
\hline 25 & $\mathrm{X}$ & $-1.99 \times 10^{-4}$ \\
& $\mathrm{Y}$ & $-1.79 \times 10^{-4}$ \\
\hline 33 & $\mathrm{X}$ & $+1.89 \times 10^{-4}$ \\
& $\mathrm{Y}$ & $+2.79 \times 10^{-5}$ \\
\hline
\end{tabular}


Table $x$. Thermal conductivity in the $z$ Direction (Through Thickness)

\begin{tabular}{|c|c|c|c|}
\hline \multirow{2}{*}{$\begin{array}{l}\begin{array}{l}\text { Nominal } \\
\text { Cu Ratio } \\
\frac{o}{6}\end{array} \\
0\end{array}$} & \multicolumn{2}{|c|}{$\begin{array}{c}\text { Testing } \\
\text { Temperature } \\
\text { (F) }\end{array}$} & \multirow{2}{*}{$\begin{array}{c}\frac{\mathrm{TC}}{\mathrm{cm}^{-1} \mathrm{~K}^{-1}} \\
1.37 \\
1.35 \\
1.34 \\
1.32 \\
1.30\end{array}$} \\
\hline & $\begin{array}{r}-40 \\
0 \\
23 \\
50 \\
100\end{array}$ & $\begin{array}{l}(-40) \\
(32) \\
(73) \\
(122) \\
(212)\end{array}$ & \\
\hline 13 & $\begin{array}{r}-40 \\
0 \\
23 \\
50 \\
100\end{array}$ & $\begin{array}{l}(-40) \\
(32) \\
(73) \\
(122) \\
(212)\end{array}$ & $\begin{array}{l}1.68 \\
1.66 \\
1.65 \\
1.63 \\
1.62\end{array}$ \\
\hline 20 & $\begin{array}{r}-40 \\
0 \\
23 \\
50 \\
100\end{array}$ & $\begin{array}{l}(-40) \\
(32) \\
(73) \\
(122) \\
(212)\end{array}$ & $\begin{array}{l}1.73 \\
1.74 \\
1.76 \\
1.73 \\
1.68\end{array}$ \\
\hline 25 & $\begin{array}{r}-40 \\
0 \\
23 \\
50 \\
1.00\end{array}$ & $\begin{array}{l}(-40) \\
(32) \\
(73) \\
(122) \\
(212)\end{array}$ & $\begin{array}{l}1.99 \\
1.97 \\
1.96 \\
1.95 \\
1.90\end{array}$ \\
\hline 33 & $\begin{array}{r}-40 \\
0 \\
23 \\
50 \\
100\end{array}$ & 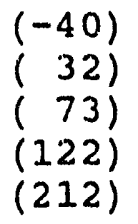 & $\begin{array}{l}1.99 \\
1.98 \\
1.97 \\
1.98 \\
2.05\end{array}$ \\
\hline
\end{tabular}




\begin{tabular}{|c|c|c|c|}
\hline \multirow{2}{*}{$\stackrel{d 0}{m}$} & 舀总 & 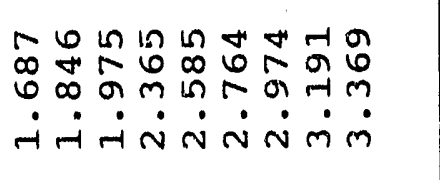 & 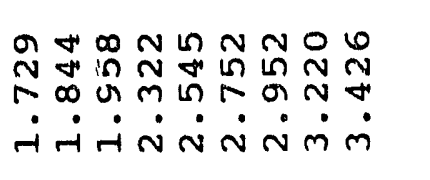 \\
\hline & 迹U & 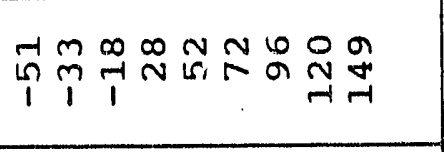 & 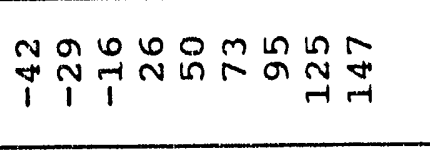 \\
\hline \multirow{2}{*}{$\stackrel{\substack{n \\
i n}}{\sim}$} & 悉 & 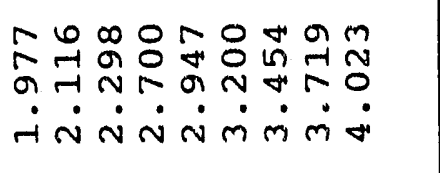 & 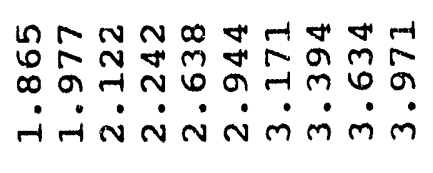 \\
\hline & $\stackrel{0}{0}_{0}^{\infty} 0$ & 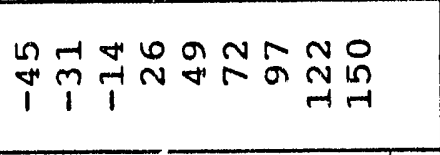 & 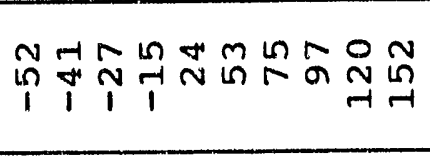 \\
\hline \multirow{2}{*}{$\begin{array}{l}\text { do } \\
\stackrel{2}{N}\end{array}$} & 毛 & 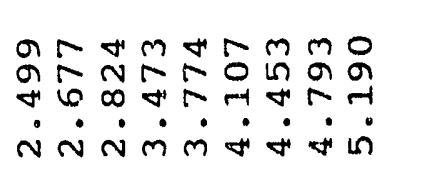 & 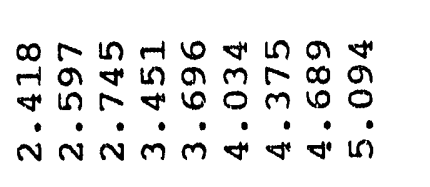 \\
\hline & $\stackrel{\dot{0}}{E} U$ & 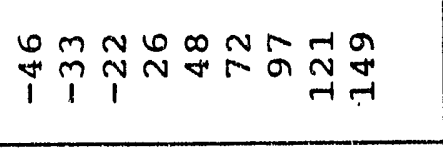 & 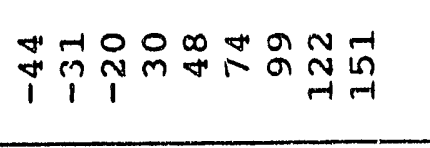 \\
\hline \multirow{2}{*}{$\stackrel{a 0}{m}$} & 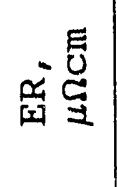 & 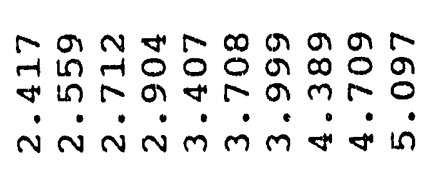 & 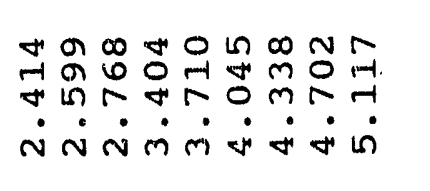 \\
\hline & $\sum_{0}^{\infty} U$ & 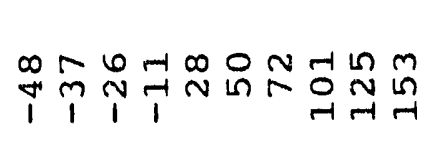 & №̛ \\
\hline \multirow{2}{*}{ మో } & 范芯 & 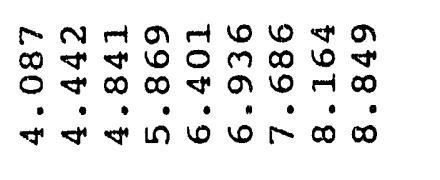 & 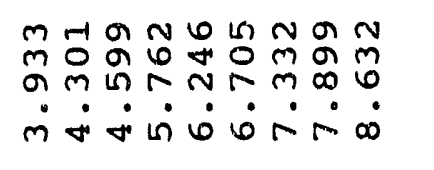 \\
\hline & 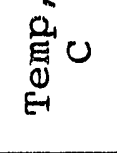 & 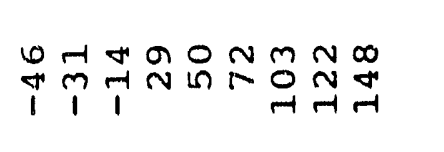 & 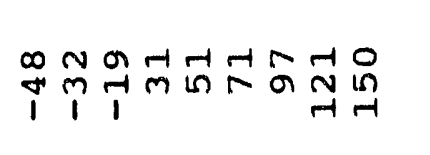 \\
\hline 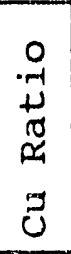 & 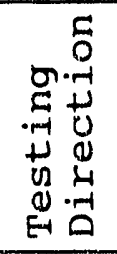 & $x$ & $>1$ \\
\hline
\end{tabular}


$\frac{\text { Table XII. Temperature Dependence of Electrical }}{\text { Resistivity (ER) }}$

\begin{tabular}{|l|l|c|c|}
\hline $\begin{array}{l}\text { Nominal } \\
\text { Copper } \\
\text { Ratio }\end{array}$ & $\begin{array}{l}\text { Equation } \\
\text { ER }=\text { at }+b \\
(t=t e m p \cdot i n c)\end{array}$ & $\begin{array}{c}\text { Coefficient of } \\
\text { Correlation } \\
r\end{array}$ & $\begin{array}{c}\text { ER } \\
\text { at } 25 \mathrm{c} \\
\mu \Omega \mathrm{cm}\end{array}$ \\
\hline 0 & $0.02405 t+5.118$ & 0.998 & 5.72 \\
13 & $0.01344 t+3.047$ & 0.999 & 3.38 \\
20 & $0.01382 t+3.065$ & 0.998 & 3.41 \\
25 & $0.01042 t+2.417$ & 0.999 & 2.68 \\
33 & $0.00877 t+2.117$ & 0.999 & 2.34 \\
\hline
\end{tabular}

Table XIII. Magnetic Susceptibility of Copper-clad Molybdenum Sheet at Room Temperature

Nominal $\mathrm{Cu}$

Ratio, \%
Magnetic

susceptibility,

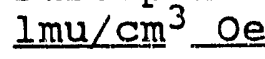

$(8.2 \pm 0.1) \times 10^{-6}$

$(5.2 \pm 0.1) \times 10^{-6}$

$(5.1 \pm 0.1) \times 10^{-6}$

$(3.7 \pm 0.1) \times 10^{-6}$

$(2.4 \pm 0.1) \times 10^{-6}$ 


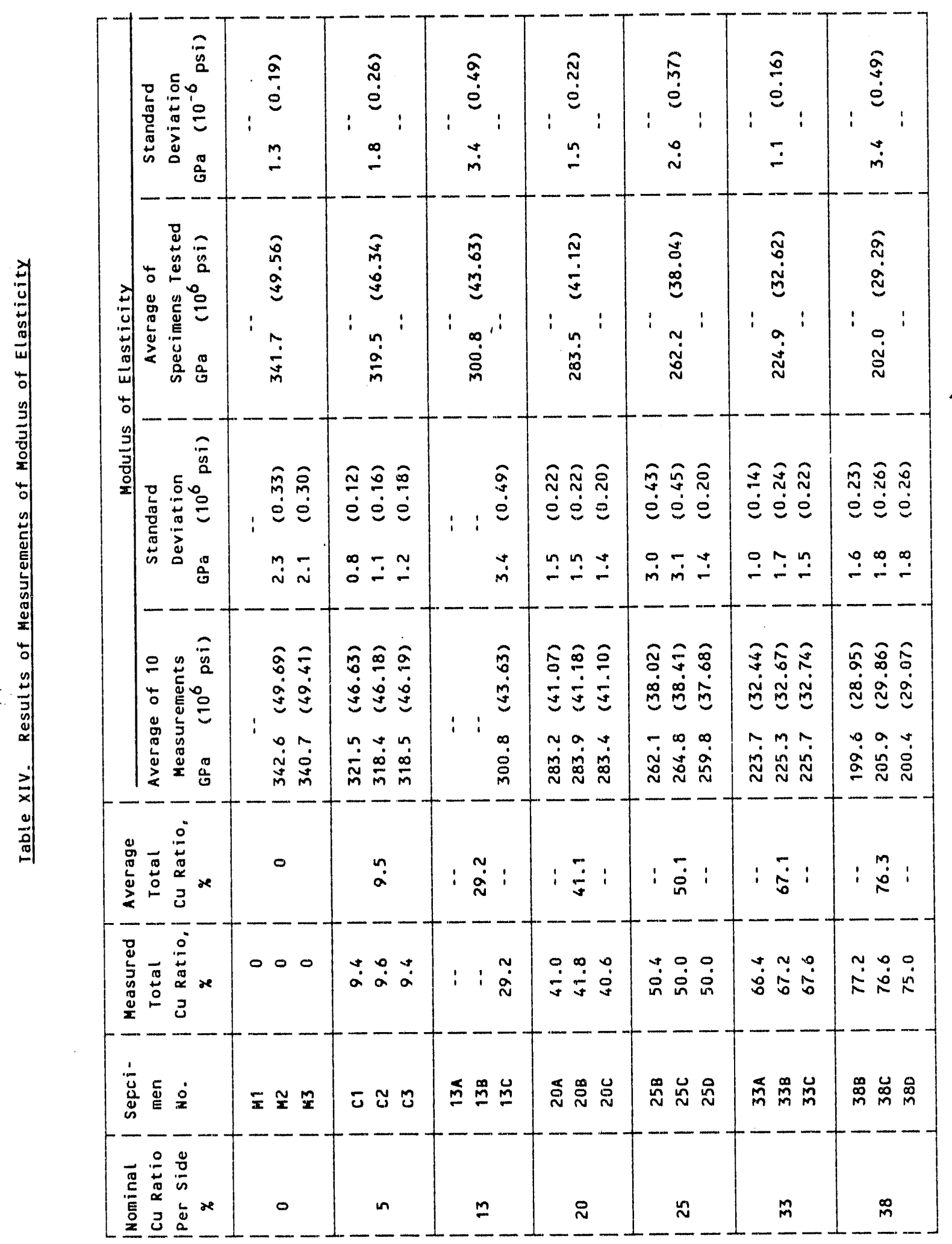




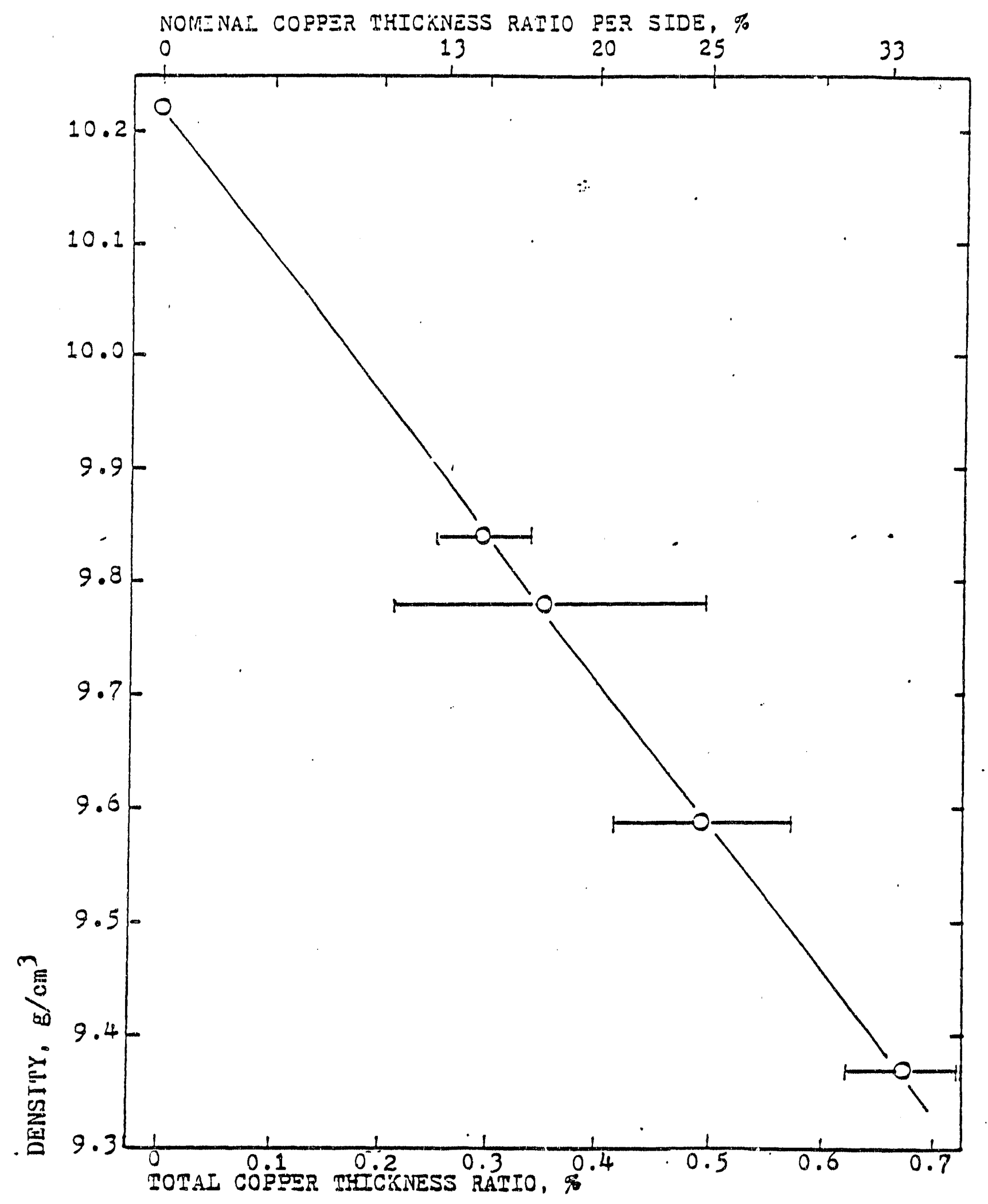

Figure 1. Effect of Copper Ratio on the Density of Copper-Clad Molybdenum Sheet 


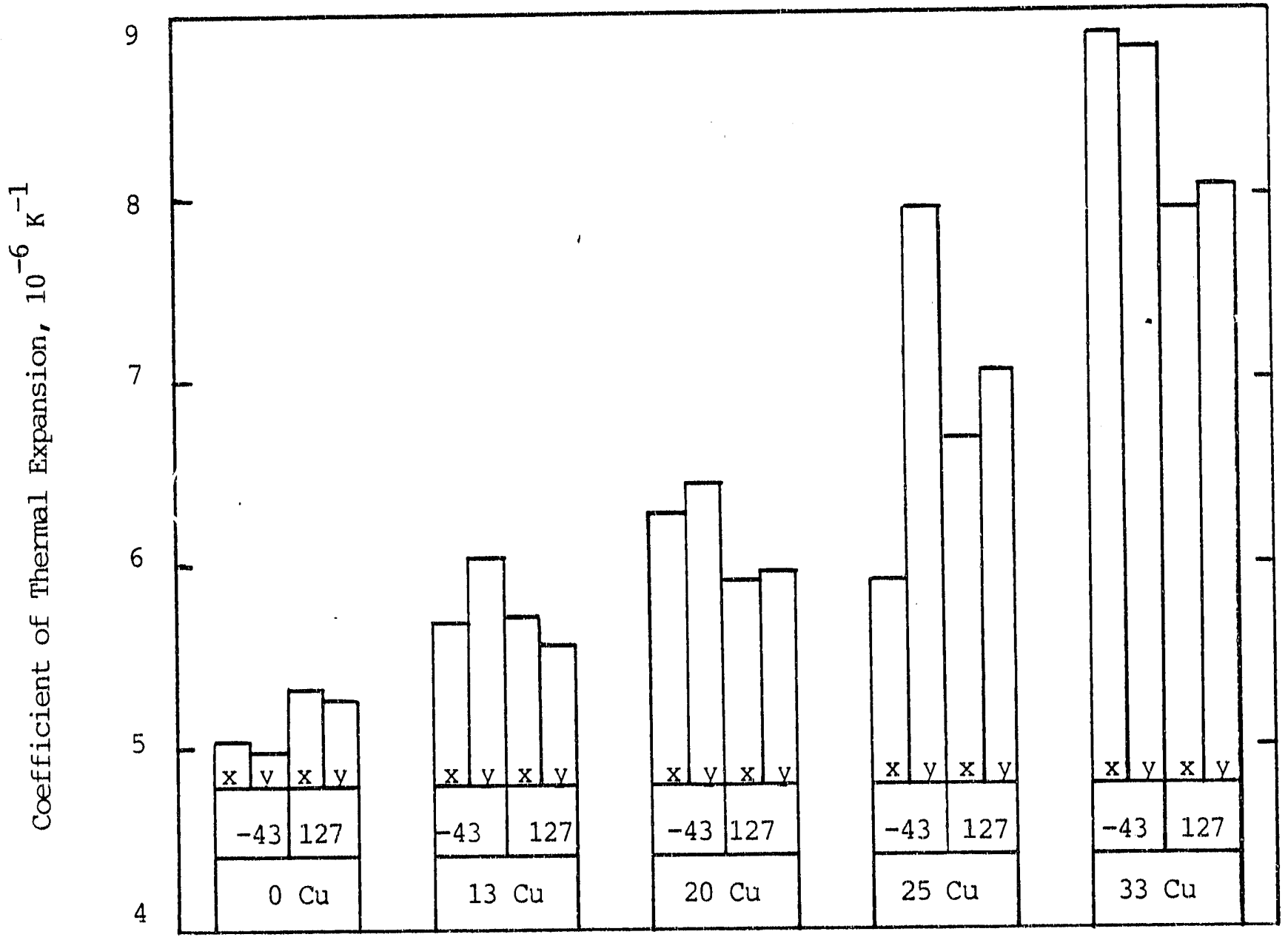

Figure 2. Effect of Nominal Copper Ratio, Temperature Range and Testing Direction on the Coefficient of Thermal. Expansion. 


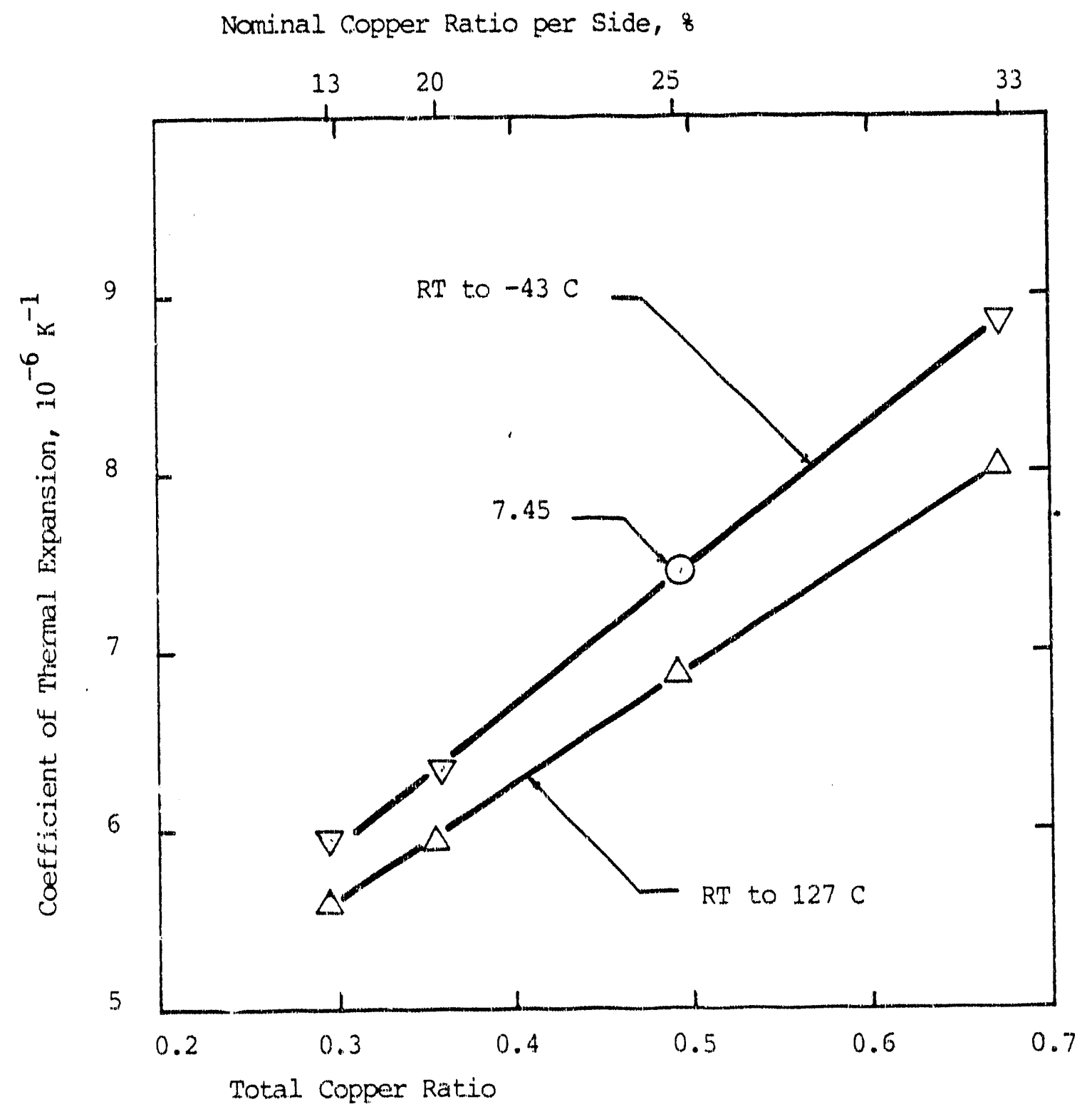

Figure 3. Effect of Copper Ratio on the Average CTE in the Temperature Ranges Indicated. 


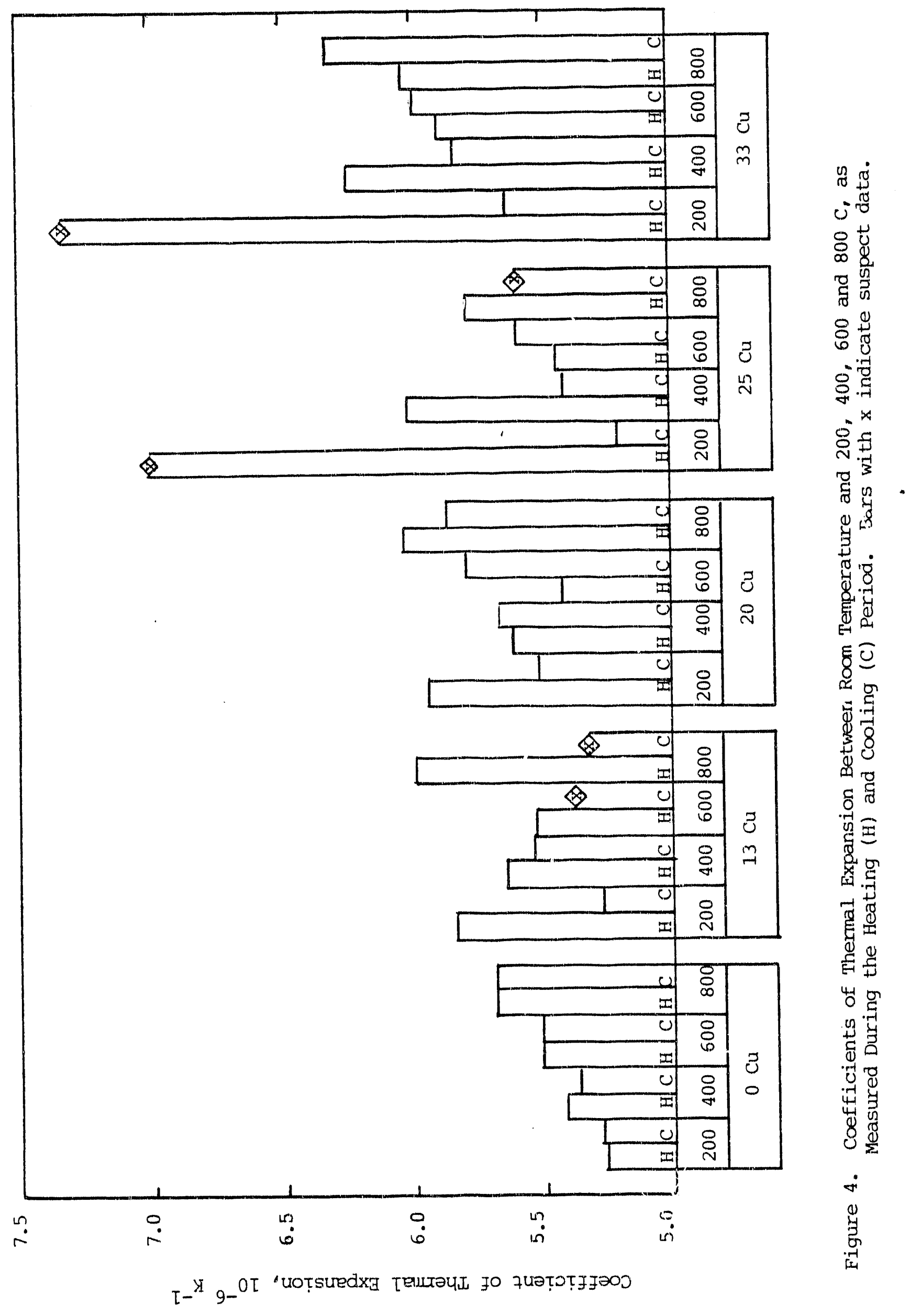




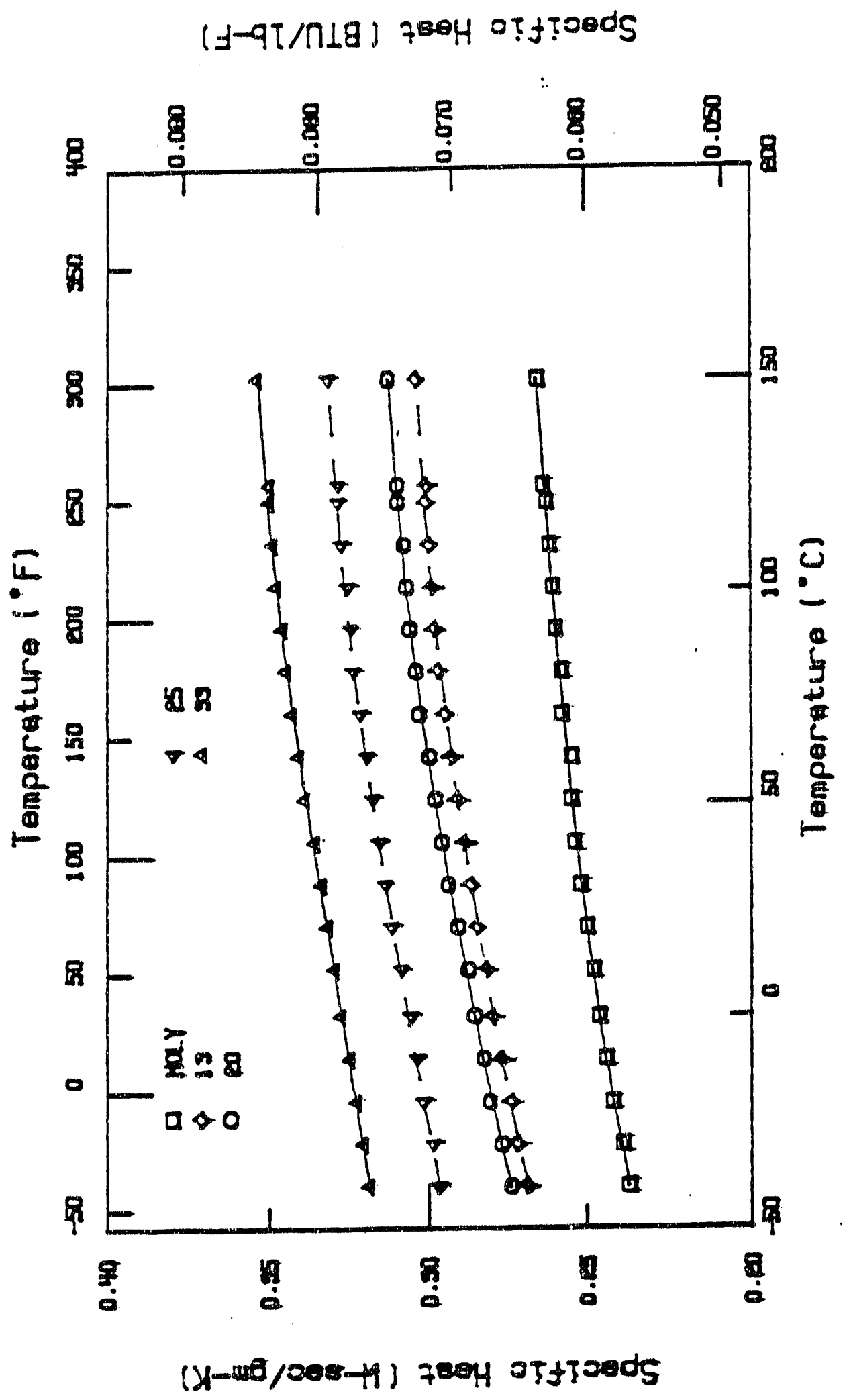

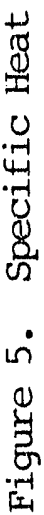




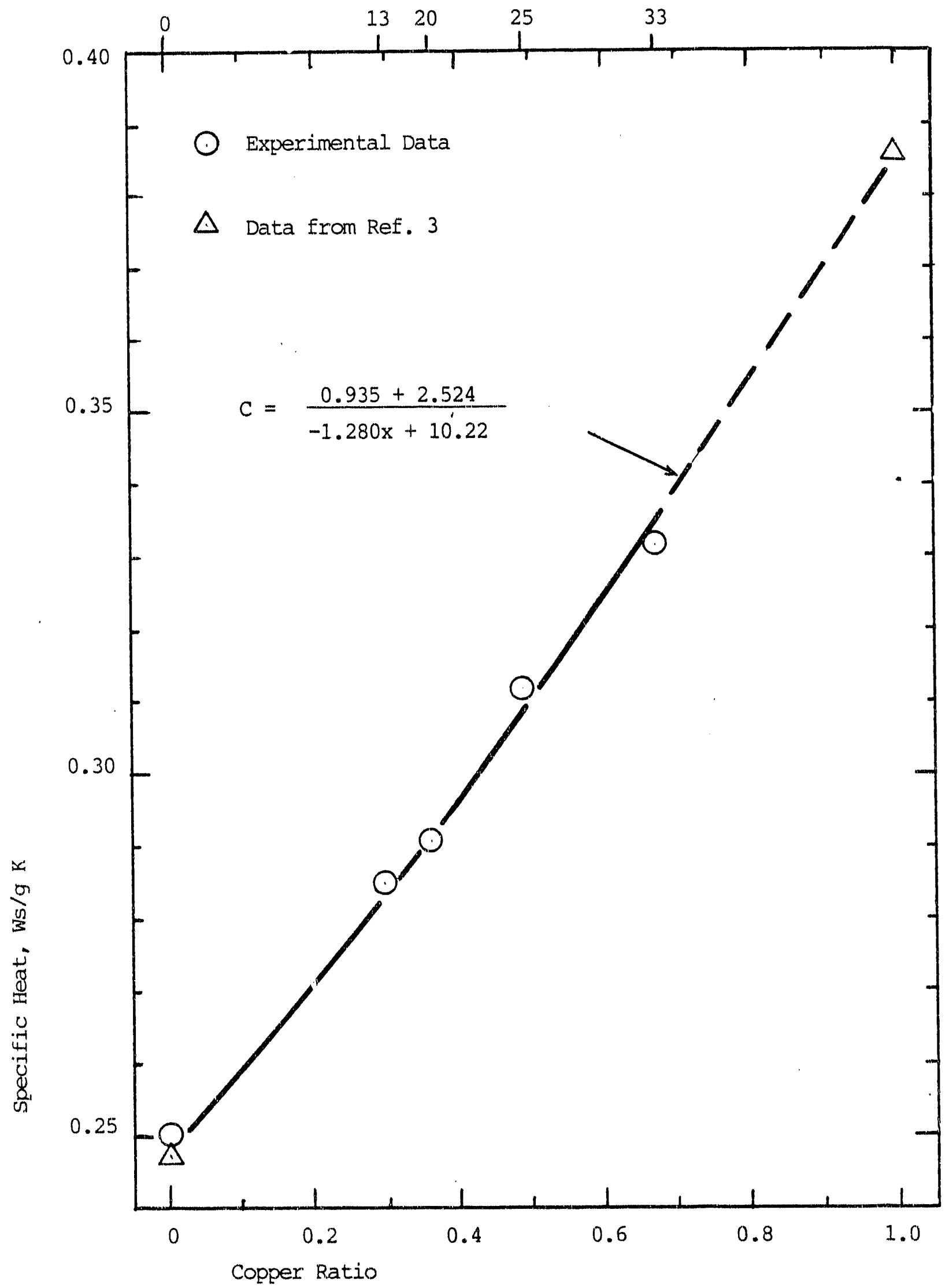

Figure 6. Effect of the Copper Ratio on the Specific Heat of Copper Clad Molybdenum sheet at $21 \mathrm{C}(70 \mathrm{~F})$. 


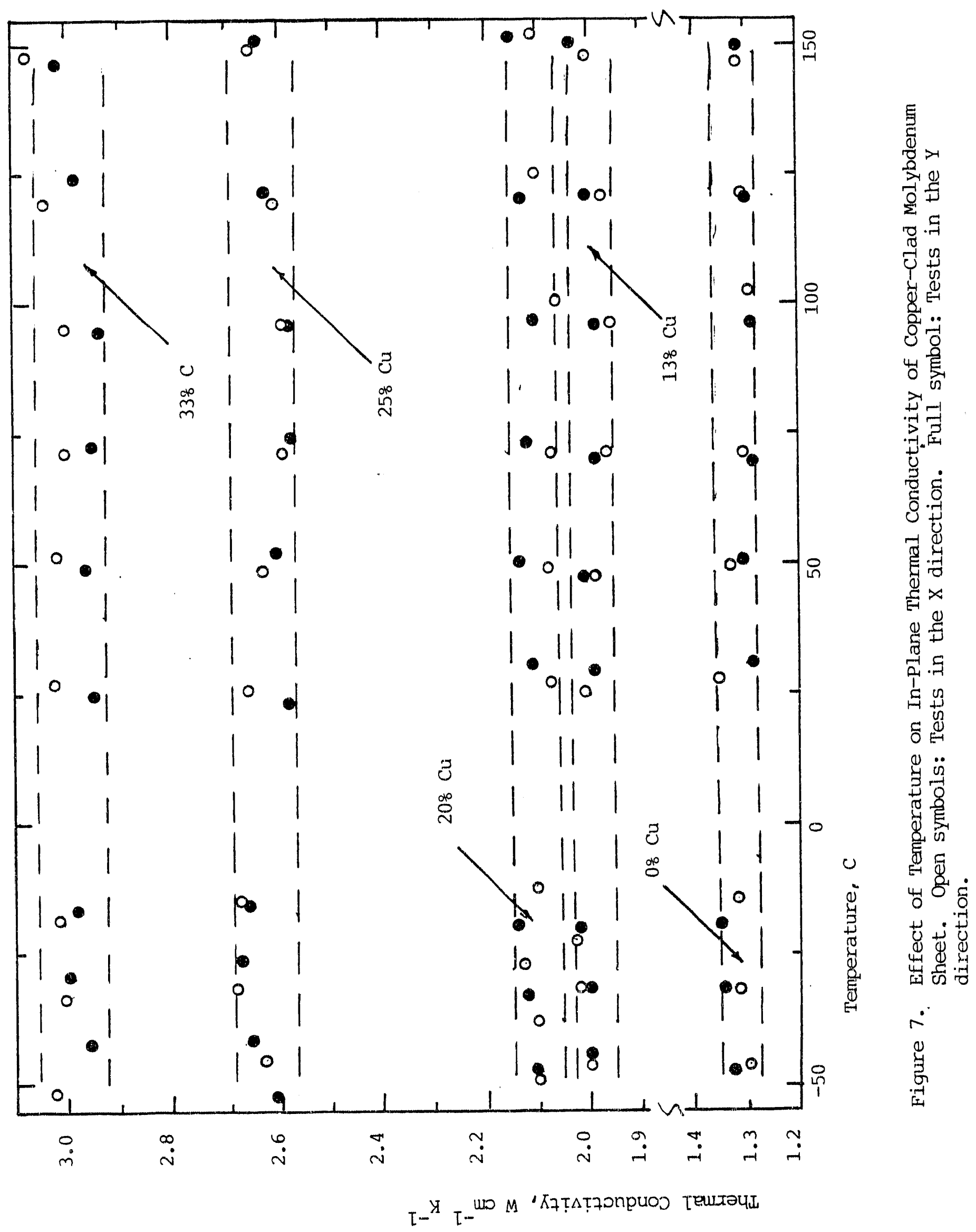




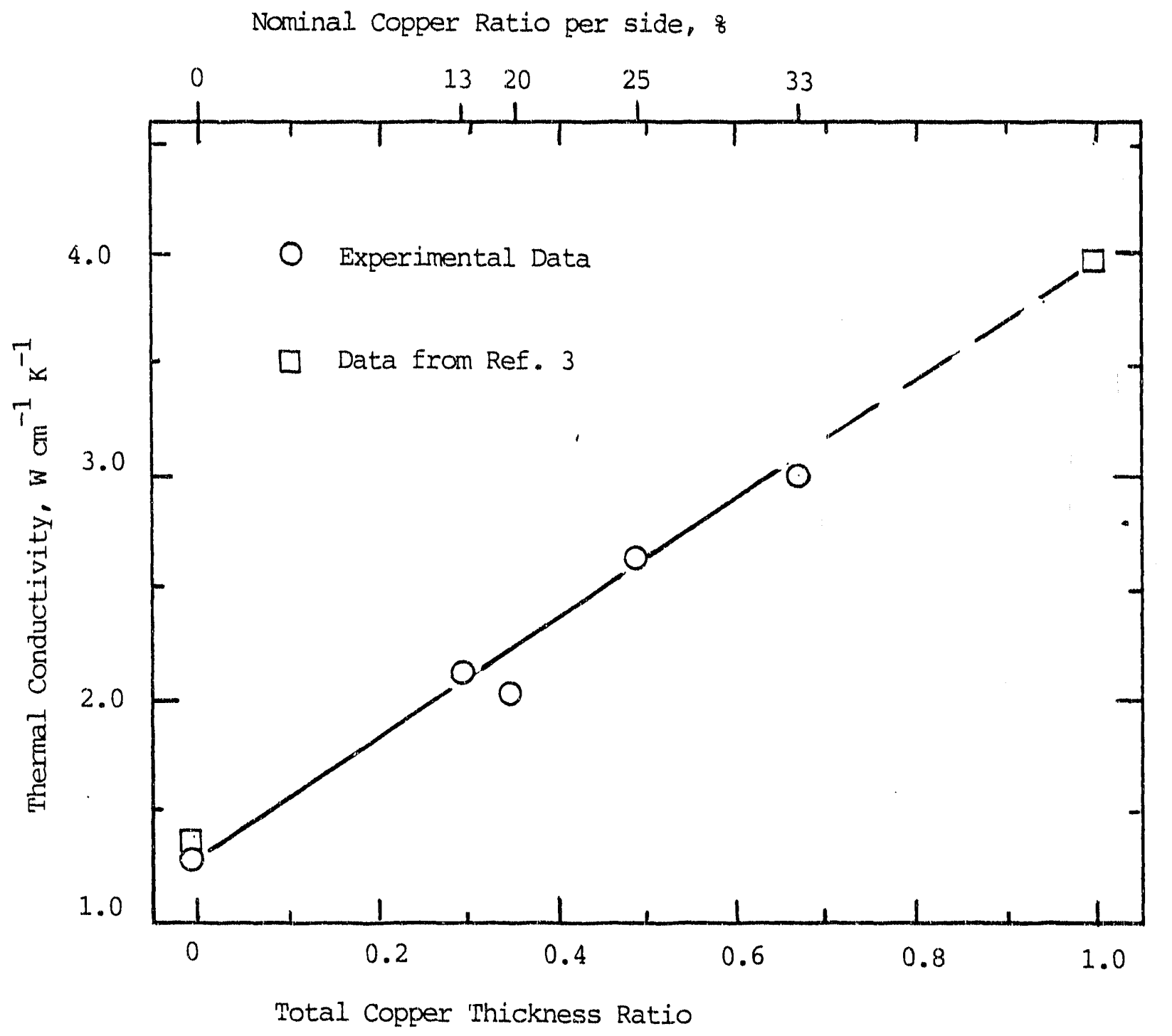

Figure 8. Effect of Copper Ratio on In-Plane Thermal Conductivity of Copper-Clad Molybdenum Sheet. 


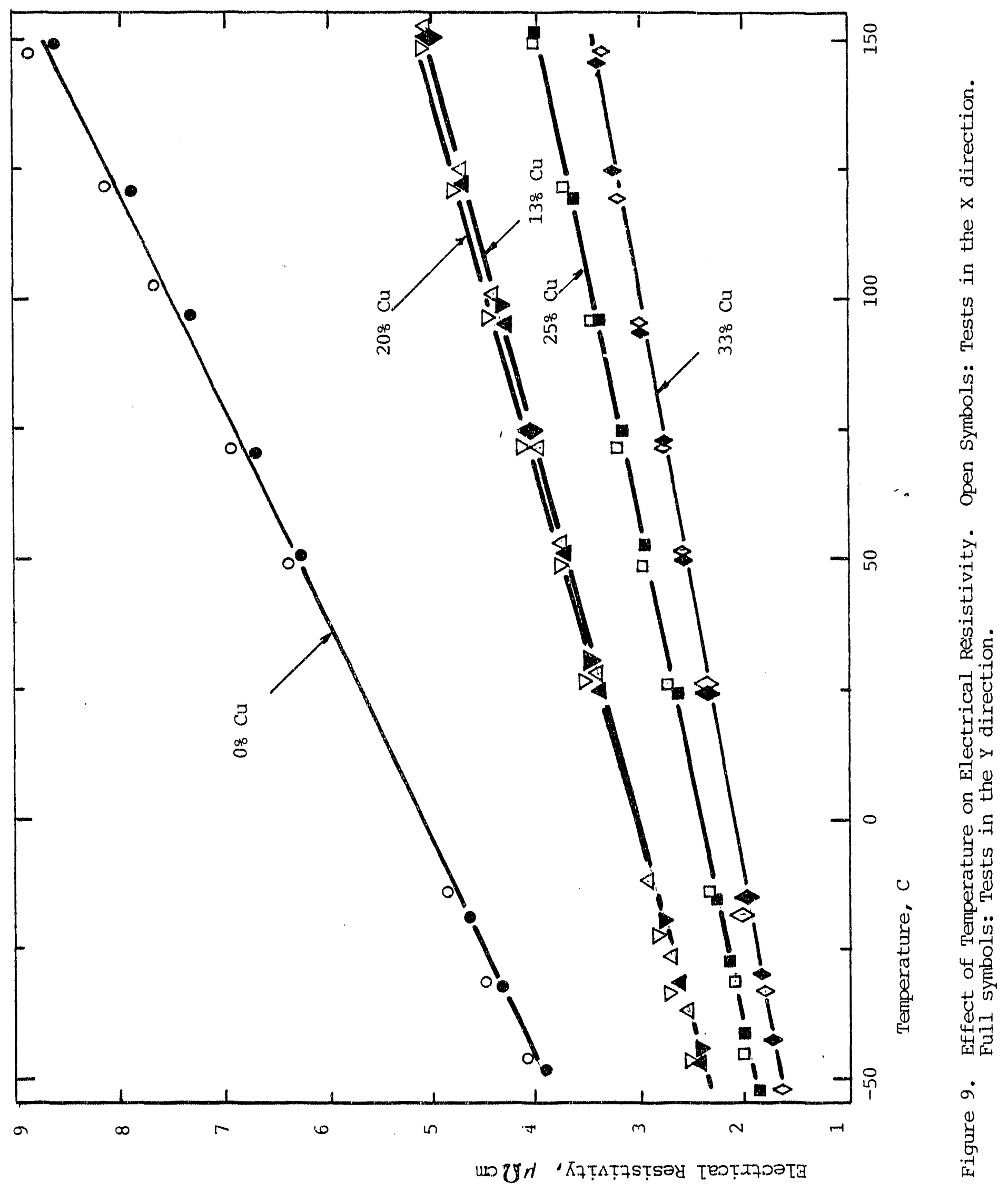




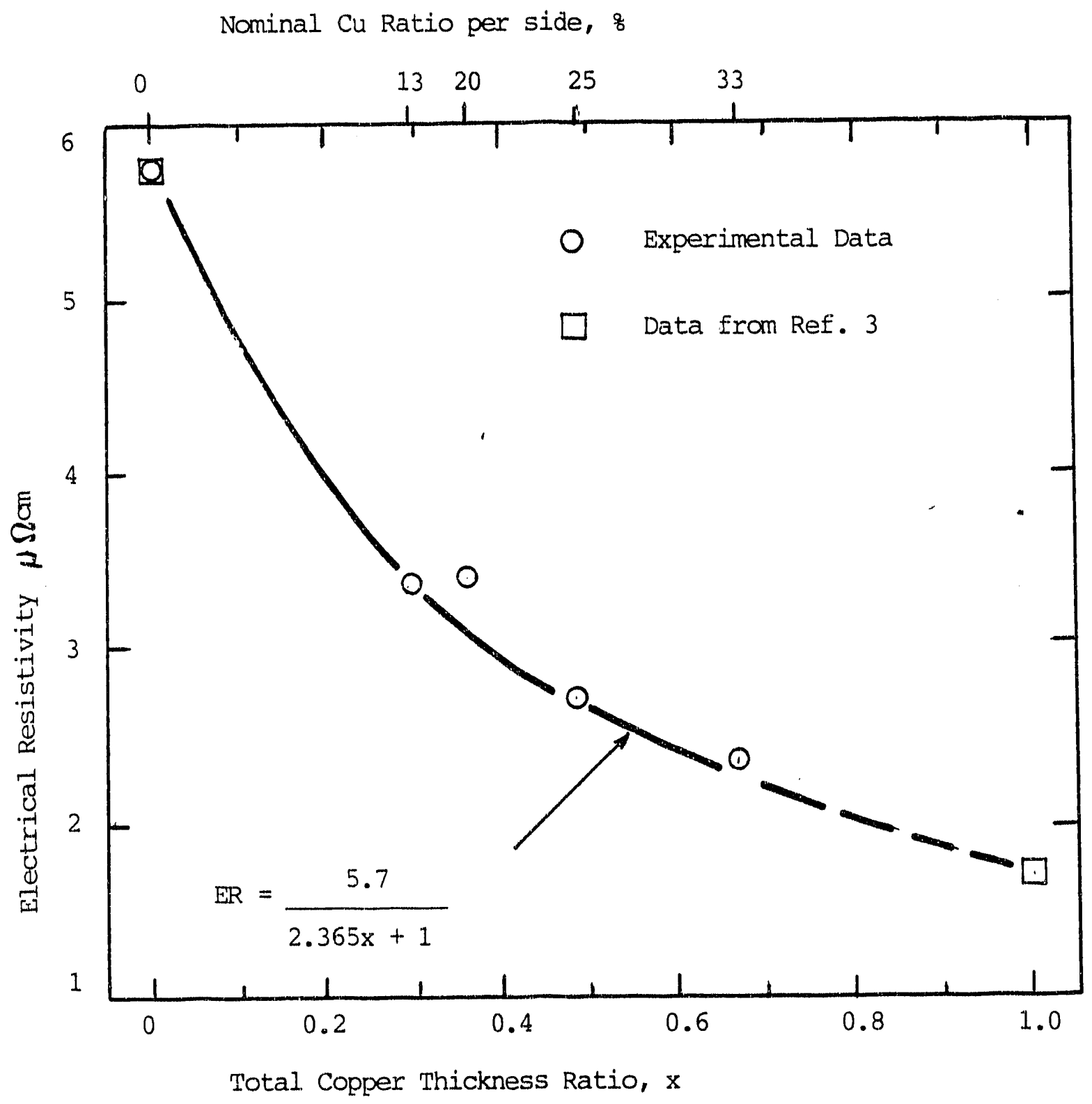

Figure 10. Effect of Copper Ratio on Room-Temperature Electrical Resistivity of Copper Clad Molybdenum Sheet 


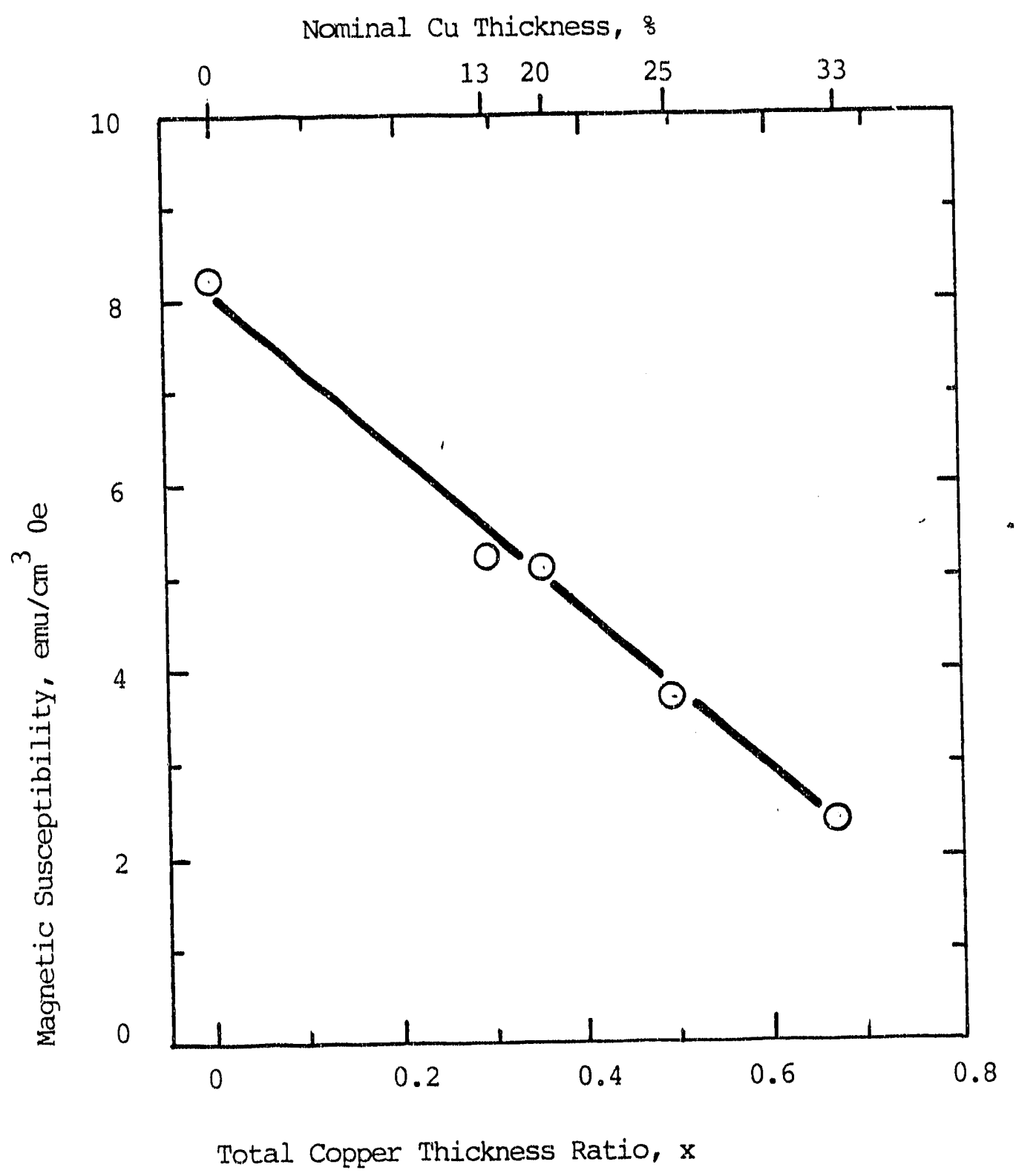

Figure 11. Effect of Copper Ratio on Room-Temperature Magnetic Susceptibility of Copper-Clad Molybdenum Sheet. 


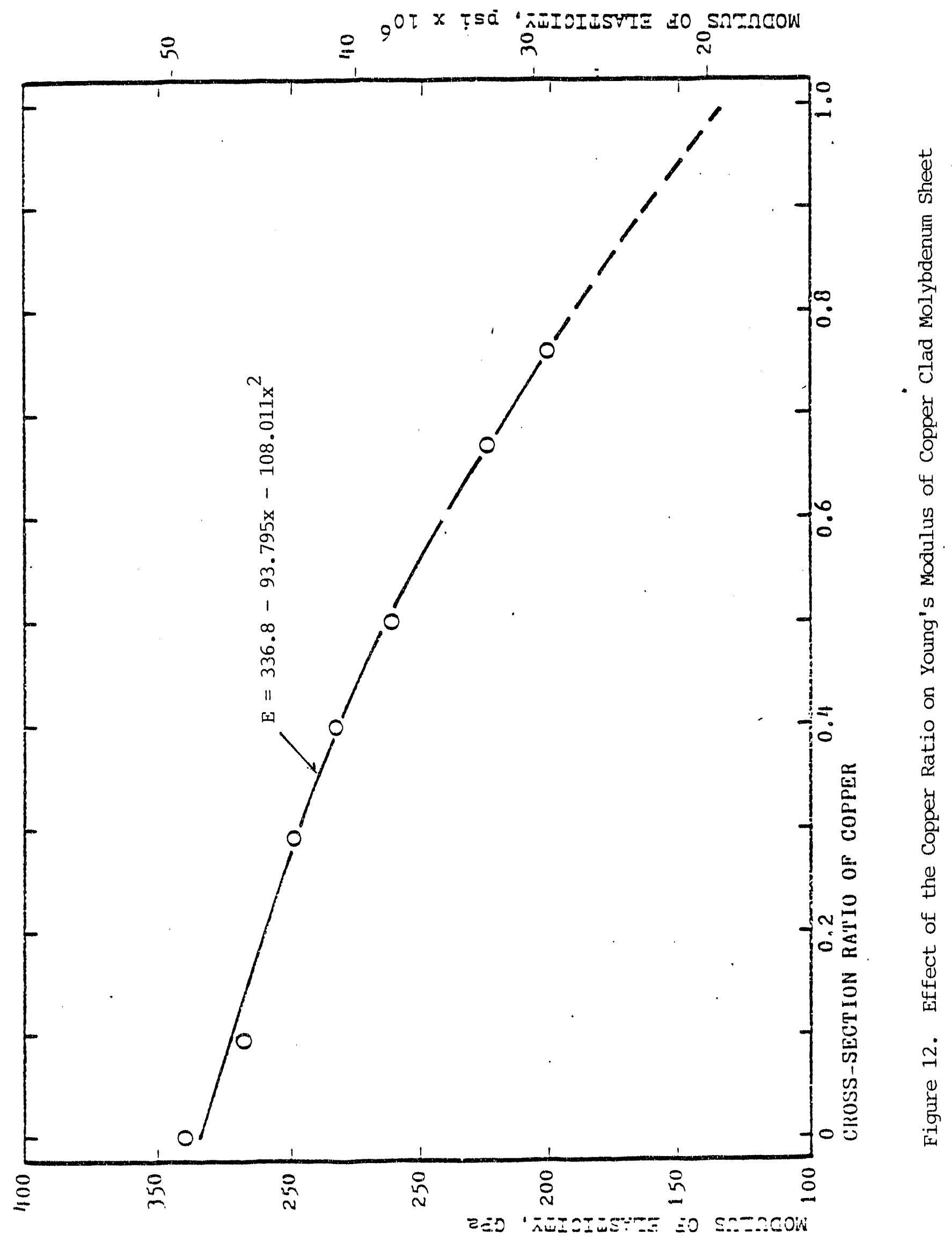



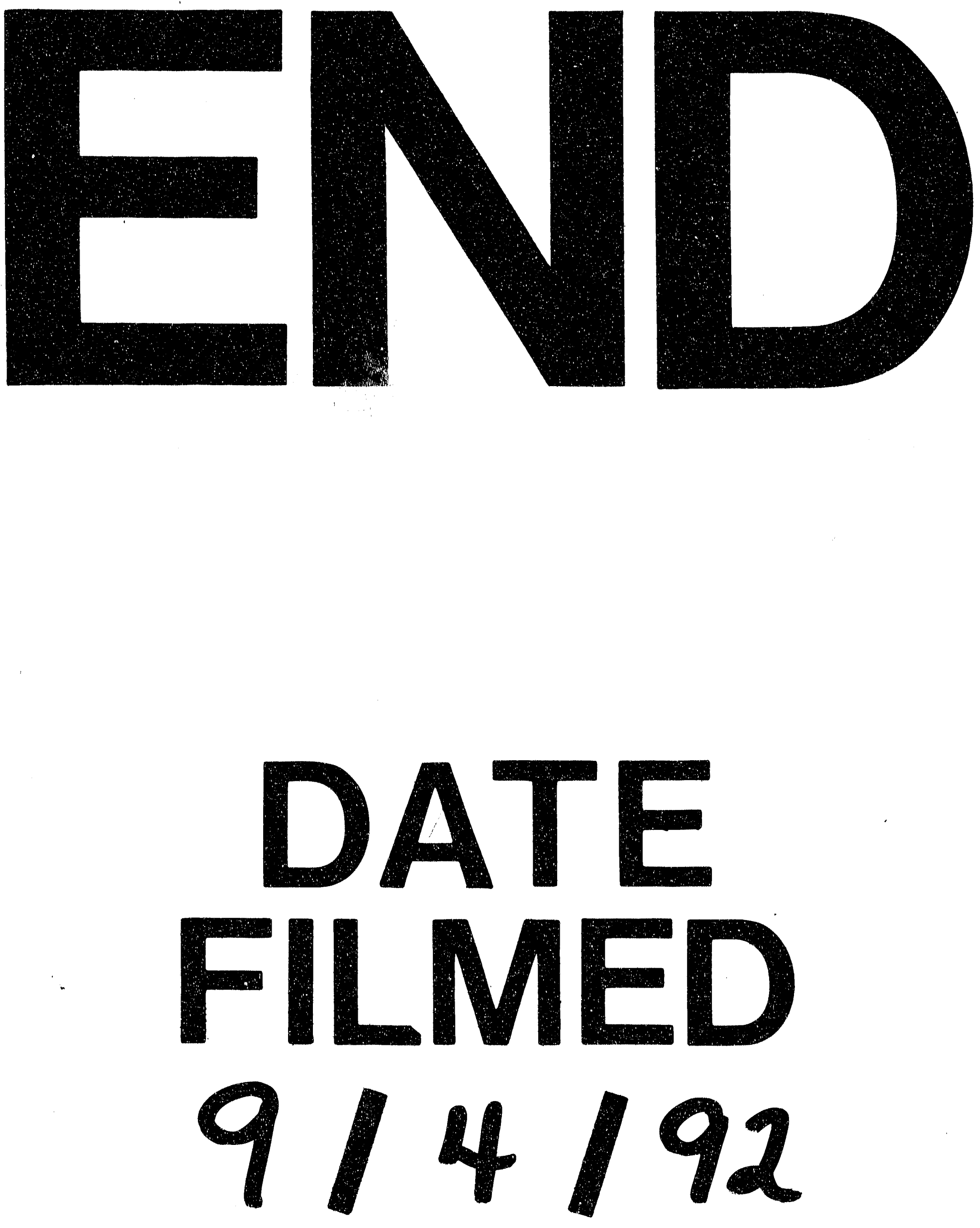
